\title{
The Tien Shan Early Paleozoic tectonics and geodynamics
}

\author{
B. S. Burtman \\ Geological Institute, Russian Academy of Sciences, Moscow, Russia \\ Received 20 May 2006; revised 15 June 2006; accepted 10 July 2006; published 20 July 2006.
}

[1] Reported in this paper are the results of the analysis and generalization of the geological, radiometric, paleomagnetic and biogeographical data obtained in the Western, Central, and Eastern Tien Shan during the study of the Late Neoproterozoic and Early Paleozoic rocks. Earlier the Tien Shan rocks belonged to the Alay-Tarim Early Paleozoic continent, as well as to a few microcontinents and oceanic basins. From the Vendian to the Late Carboniferous the Turkestan oceanic basin separated the Alay-Tarim continent from the assemblage of microcontinents and island arcs the rocks of which compose the North Turkestan domain of the present-day Tien Shan. During the Early Paleozoic the rocks of this domain composed the Borohoro, Issyk Kul, and Syr Darya microcontinents. These microcontinents were separated by the Terskey and Ili oceanic basins, where oceanic island arcs originated and disappeared. These oceanic basins were closed during the collision of the microcontinents in the Early Ordovician (Terskey Basin) and in the Silurian (Ili Basin). The structural features of the region also described and discussed in this paper, as well as the tectonic processes that operated in the Early Paleozoic, including their evolution and geodynamics. INDEX TERMS: 1500 Geomagnetism and Paleomagnetism; 1744 History of Geophysics: Tectonophysics; 8140 Tectonophysics: Ophiolites; 8150 Tectonophysics: Plate boundary: general; KEYWORDS: Tien Shan, microcontinent, paleoocean, island arc, Lower Paleozoic.

Citation: Burtman, B. S. (2006), The Tien Shan Early Paleozoic tectonics and geodynamics, Russ. J. Earth. Sci., 8, ES3003, doi:10.2205/2006ES000202.

\section{Introduction}

[2] The Tien Shan mountain system, named after the Chinese term of "sky-high mountains", is one of the greatest mountain systems of Asia. It is located in the territory of West and East Turkestan, the boundary between them marking the state boundary between China and Kyrghystan and Kazakhstan. The geology of the Western and Eastern Turkestan was studied independently, the information exchange being complicated by complex political relations and the language barrier, which resulted in the difficulty of geologic data correlation. In this paper we have to give up the use of the well-known name of this geological province, such as the "Middle Tien Shan Province", since different provinces are described under this name in Western and Eastern Turkestan.

[3] There are numerous Russian publications for the Tien Shan geology. Most of the generalized publications are restricted to the territories of single states, such

Copyright 2006 by the Russian Journal of Earth Sciences. ISSN: 1681-1208 (online) as Kazakhstan, Kyrghystan, Uzbekistan, or Tadjikistan [Akhmedov, 2000; Baratov, 1976; Bekzhanov et al., 2000; Dalimov and Shayakubov, 1998; Osmonbetov et al., 1982; et al.]. Extensive list of references is provided by [Burtman, 2006].

[4] Geographic provinces. The Tien Shan area is subdivided conventionally into the eastern, central, and western geographic provinces. The boundary between the East and Central Tien Shan areas passes along the $80^{\circ} \mathrm{E}$ meridian, between the Central and Western Tien Shan areas along the Fergana, Atoynak, Talas, and Major Karatau ridges (Figure 1). Geologically, the boundary between the Central and Western Tien Shan regions follows the Late Paleozoic Talas-Fergana strike-slip fault.

[5] The Eastern Tien Shan and part of the Central Tien Shan belong to the drainless geographical province, known as "Central Asia". The Syr Darya and Amu Darya river basins and the areas surrounding them are classified as the "Middle Asia" geographic province.

[6] Tectonic domains. For more than 300 million years (from the Vendian to the Late Carboniferous) the Turkestan oceanic basin separated the geological provinces 


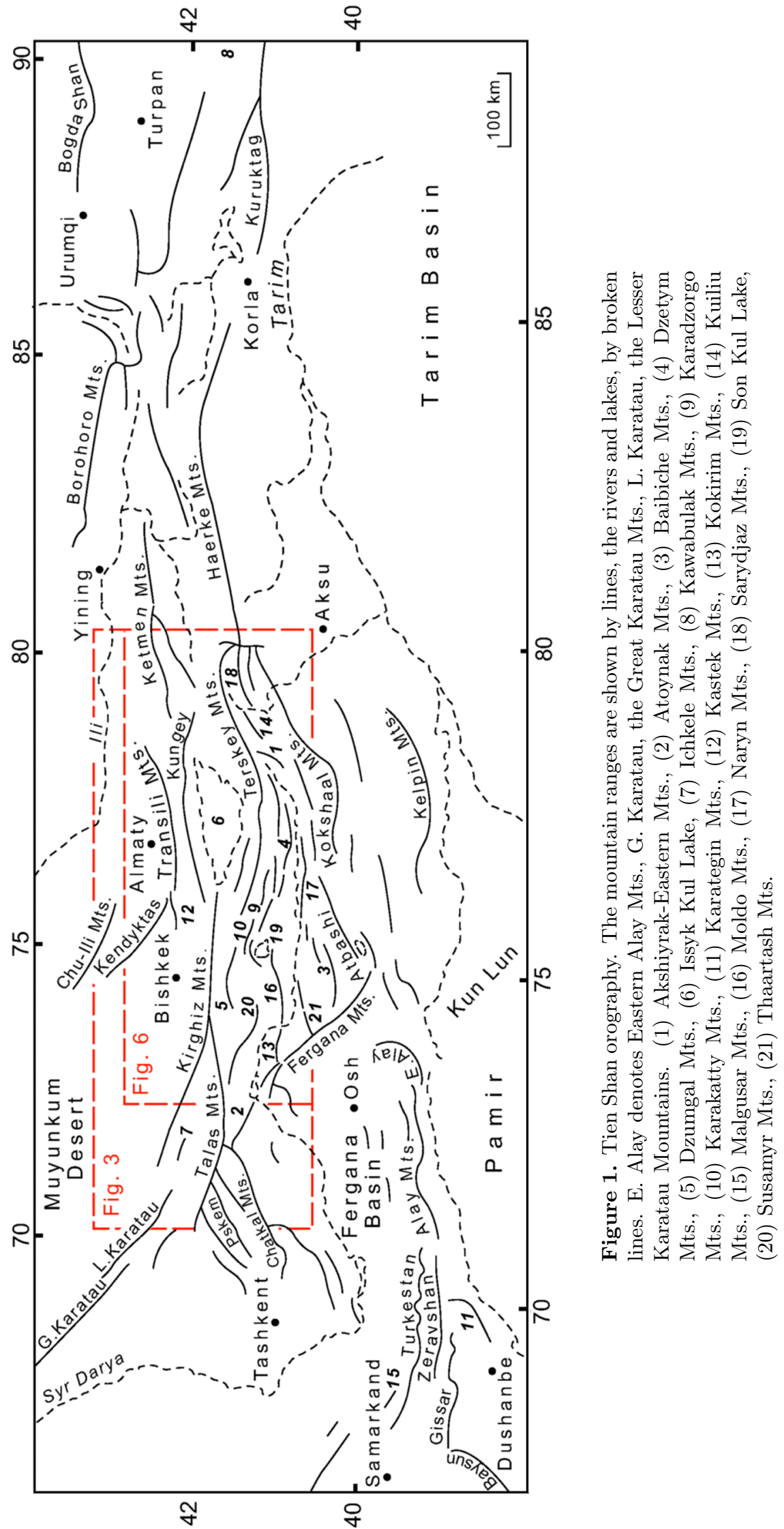




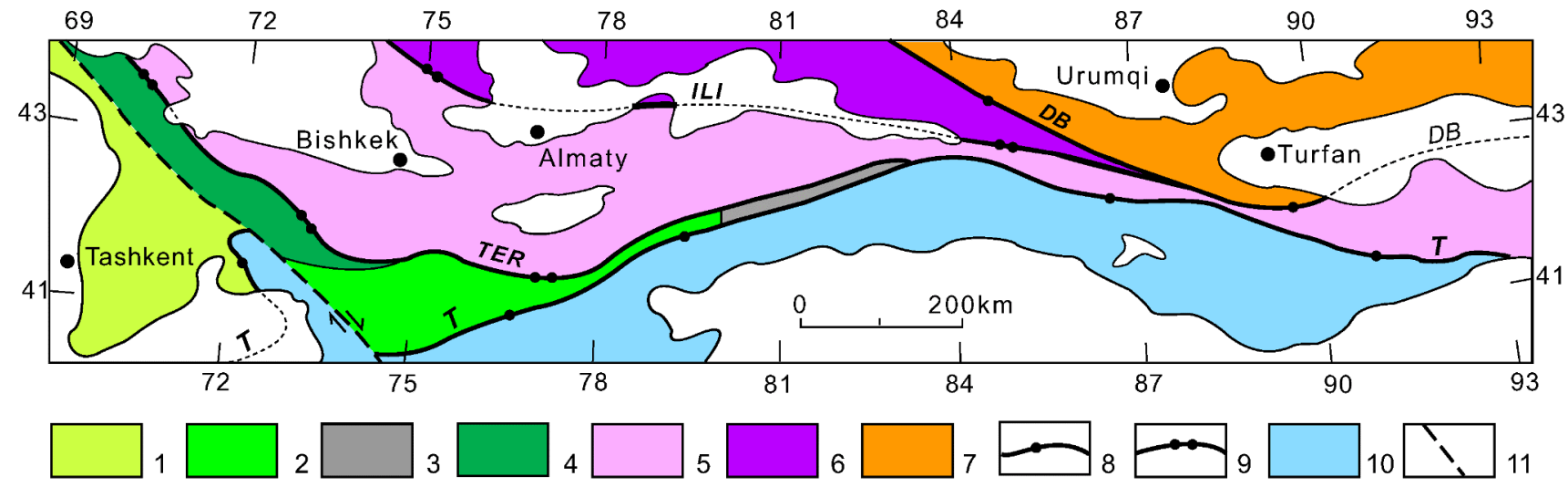

Figure 2. The Early Paleozoic terrains and tectonic zones of the North Turkestan Domain. (1-6) The Early Paleozoic terrains and tectonic zones of the North Turkestan Domain: the Syr Darya (1-4), Issyk Kul (5), and Borohoro (6) terrains. The Syr Darya Terrain consists of the Chatkal (1), Naryn (2), Nalaqin (3), and Talas (4) tectonic zones. (7) The Late Paleozoic Bogda Shan terrain, (8) the Late Paleozoic oceanic sutures: (DB) Dzungar-Balkhash and (T) Turkestan; (9) The Early Paleozoic oceanic sutures: ILI - the Ili suture, TER - the Terskey suture; (10) South Turkestan Domain, (11) Talas-Fergana strike-slip fault.

of different geological histories. The suture of this oceanic basin (Figure 2) is the boundary between the North Turkestan and South Turkestan tectonic domains [Burtman, 1997]. The southern boundary of the South Turkestan domain is the Kun Lun oceanic basin suture which divides the South Tien Shan and Tarim from the Pamir and Tibet.

[7] Terminology. Most of the terms used in this paper are generally accepted ones, the use of which need be explained.

[8] Oceanic basin. This term defines the oceanic type of the earth crust in the study area is used regardless of the size and depth of the basin. This term is applicable to paleooceans, back- and inter-arc basins, and to intercontinent rifts with oceanic crust.

[9] Microcontinent, continental island arc. In the Paleozoic the Tien Shan rocks composed a few tectonic blocks, having an old continental crust and separated by oceanic basins. A continental block of this kind can be ranked as a microcontinent or as a continental island arc, volcanic or nonvolcanic. Most of the modern structural features of this kind are island arcs. The Tien Shan Paleozoic structural features did not preserve the form of a primary arc and were often curved repeatedly in the directions, different from the primary ones. I preferred to call them "microcontinents".

[10] Proterozoic stratigraphic units. Since there is no universally accepted scale for the Proterozoic, I preferred the scale used in Middle Asia, where the Riphean (1600-800 Ma) is followed by the Sinian (800-540 Ma). The latter consists of two systems, namely, the Lower Sinian and Vendian, which correspond, roughly, to the Neoproterozoic-II (Cryogenian) and to the Neoproterozoic-III (Idiacarian) in the stratigraphic scales discussed by the International Stratigraphic Commission [Gradstein et al., 2004].

\section{North Turkestan Domain}

[11] The sutures of the Terskey and Ili Early Paleozoic oceanic basins divide the territory of the North Turkestan Domain into three parts, which existed as microcontinents during the Early Paleozoic. The Borohoro Terrain is situated north of the Ili oceanic suture, the Issyk Kul Terrain resides between the Ili and Terskey oceanic sutures, and the Syr Darya Terrain is situated south and west of the Terskey suture (Figure 2).

\subsection{Syr Darya Terrain}

[12] This terrain consists of the Chatkal, Naryn, Nalaqin, and Talas tectonic zones, separated by oceanic sutures and late Paleozoic faults (Figure 2).

\section{Chatkal Zone}

[13] Basement. The oldest rocks compose the Chatkal Ridge. These are metamorphic and migmatized peridotites, pyroxenite, hornblendite, serpentinite, gabbro-amphibolite, garnet amphibolite (Kassan ophiolite), and crystalline schist. The U-Pb isochronous age of $1920 \pm 20$ million years was found for the zircons from the garnet-mica schist [Bakirov et al., 2003]. The ophiolites are overlain unconformably by metamorphic flysch which was supposedly dated Riphean. Riphean $\mathrm{Pb}-\mathrm{Pb}$ and $\mathrm{K}-\mathrm{Ar}$ ages were also found for the granites of the Pskem and Talas ridges.

[14] Vendian. At the southern slope of the Talas Ridge, the granites having a K-Ar age of 825-915 Ma are 


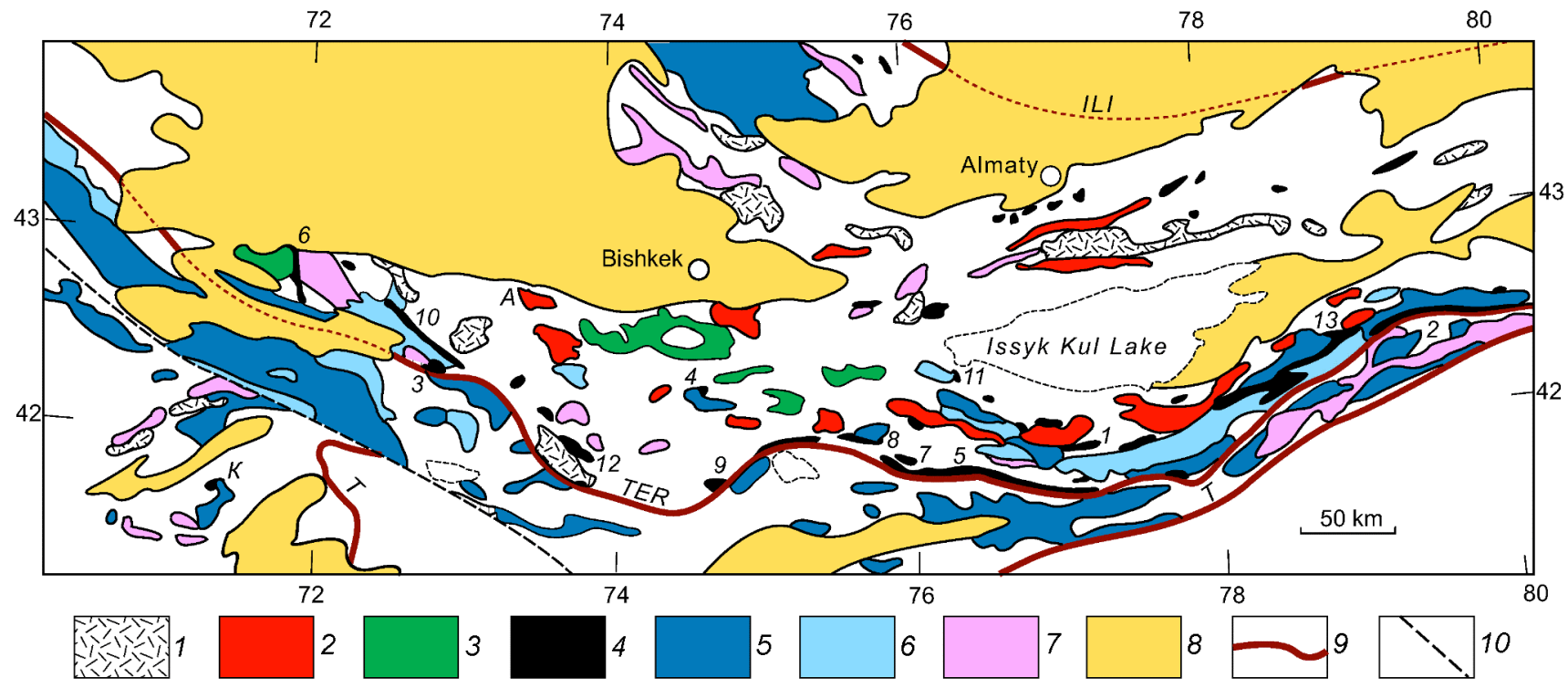

Figure 3. The Vendian and Early Paleozoic rocks of the North Turkestan Domain in the Western and Central Tien Shan: (1-3) Middle and Upper Ordovician: (1) the deposits containing subduction volcanics, (2) I-type granitoids, (3) the sediments of intracontinental basins; (4-6) the Vendian and Middle Ordovician rocks: (4) the rocks of the oceanic crust and oceanic island arcs, (5-6) sediments dominated by the rock material of the continental slope (5) and shelf (6); (7) the Sialic basement (Riphean and Lowe Sinian); (8) Mesozoic and Cenozoic rocks; (9) oceanic sutures: (ILI - Ilian, TER - Terskey, T - Turkestan); (10) Talas-Fergana strike-slip fault; (1-13) ophiolite allochthon fragments in the Issyk Kul Terrain: (1) Ashuldebe, (2) Ashuturuk, (3) Balachichkan, (4) Dzumgal, (5) Kapkatash-Dzetymbel, (6) Karaarcha, (7) Karadzorgo, (8) Karakatty, (9) Karakiche, (10) Kenkol, (11) Tegerek, (12) Toluk, and (13) Turgenaksu. (K) Karaterek ophiolites, (A) Aspara Massif of tonolite and granodiorite.

overlain by tuffaceous rocks and trachybasalt, trachyandesite, and trachyte lavas (Mursash Formation, $200 \mathrm{~m}$ thick). These rocks are overlain by a rock sequence including diamictite layers. This rock sequence is widespread in the Sandalash Ridge (Uzunbulak, Shorashu, and Ayakterek formations, $2000 \mathrm{~m}$ thick). The basis of the visible rock sequence is composed of unsorted conglomerates with crystalline schist pebbles, which are replaced upward by flysch. The middle of this rock sequence includes a diamictite layer with pebbles and boulders of granite, crystalline and metamorphic schists, and carbonite, siliceous, and effusive rocks. Similar deposits are widespread also in the Pskem Ridge, at the northern slope of the Chatkal Ridge, and also in the Major Karatau Ridge. The diamictite-bearing rocks of the latter contain Vendian microfossils and Early Cambrian accritarches.

[15] These deposits seem to have accumulated in a basin of rift origin. They are overlain with a stratigraphic unconformity by the rocks containing Early Cambrian fossils.

[16] Cambrian and Ordovician. The Early Paleozoic was marked by the formation of turbidites in the Chatkal zone. In the lower part of the rock sequence the turbidites have an argillaceous-carbonate-siliceous composition and contain diamictite lenses. The Ordovician part of the rock sequence includes basic and intermediate tuffs and basalts. These rocks accumulated under deep-sea conditions, which were interrupted by the accumulation of shallow-sea limestones and other rocks (Sandalash, Beshtor, Ayutor, and other formations, totaling $2000 \mathrm{~m}$ in thickness). Found at the lower levels of this rock sequence were Early Cambrian brachiopods. Those found at the higher levels were MiddleLate Cambrian trilobites, as well as Early Ordovician, Middle Ordovician, and Caradocian trilobites, graptolites, and conodonts.

[17] The Vendian-Ordovician rock sequence is devoid of any angular unconformities. The Lower Silurian rocks rest conformably on the Ordovician rocks or with erosion without any angular unconformities, whereas the Devonian rocks show angular or azimuthal unconformities.

[18] Kara-Terek ophiolites (see K in Figure 3). A tectonic block from the northern slope of the Chatkal Ridge includes metamorphic ophiolites and Ordovician deep-sea volcanogenic sediments (Hristov et al., 1999). Tectonically related are pyroxenites, serpentinites, gabbro-amphibolites, and actinolite schists, totaling $1000 \mathrm{~m}$ in thickness, and a sequence of randomly metamorphosed stratified rocks, more than $1000 \mathrm{~m}$ thick. The latter is composed of distal terrigenous flysch with Arenigian-Llandeilo conodonts. It includes thick layers of pillow and tubular amygdaloidal basalts, tuff, and tuffaceous sandstones, as well as sandstone, argillite, and chert layers. These rocks can be fragments of an oceanic island arc. 


\section{Naryn Zone}

[19] Basement. Abundant in the eastern segment of this zone, namely, in the Kuiliu and Sarydjaz ridges, are gneiss, amphibolite, marble, and crystalline schists (Kuiliu Formation). Zircons of two generations found in the gneiss and crystalline schists were dated: their U-Pb isochrone ages were found to be 2.6 and 1.9 billion years [Kiselev et al., 1993]. A higher stratigraphic position is occupied by a sequence of volcanic and terrigenous rocks, widespread in the Dzetym, Naryn, and Eastern Akshiyrak ridges, known as the Major Naryn Formation, supposed to be 2000 m thick. In spite of its doubtful continuity, this rock sequence has the following structure. Its lower level is composed of rhyolite and tuff, penetrated by granite dikes and sills. Using the zircons from these rocks, their $\mathrm{U}-\mathrm{Pb}$ age was found to be 1250-1325 Ma. The intermediate layer is composed of rhythmically alternating terrigenous rocks, varying from conglomerates to pelite, with limestone interlayers and lava flows. The top of this rock sequence is composed of rhyolite and its tuff, whose $\mathrm{U}-\mathrm{Pb}$ ages were found, using their zircons, to be $705 \pm 10 \mathrm{Ma}$ and $830 \pm 40 \mathrm{Ma}$ [Kiselev et al., 1993].

[20] Judging by their lithology and structure, the Late Riphean and Early Sinian rocks had accumulated in a continental rift.

[21] Vendian. The rocks described above are overlain with angular unconformity by a rock sequence composed of conglomerates, arkose sandstones with iron-manganese concretions, acid, intermediate, and basic tuffs and tuff turbidites (Sarybel, Kashkasu, Zhargalach, and other formations). The volcanic rocks (up to $1000 \mathrm{~m}$ thick) are distinguished by elevated alkalinity and antidrome sequence of eruptions, varying from rhyolite, dacite, and trachyandesite in the lower part of the rock sequence to trachybasalt in its upper part. The accumulation of these rocks in a continental rift seems to be most probable.

[22] These rocks are followed conformably by a rock sequence including diamictites (Baikonur, Dzetymtau, Dzhakbolot, and Ottuk formations, $3000 \mathrm{~m}$ ). In the Naryn Ridge these rocks occur as large rhythms, composed of block, pebble, and gravel diamictites, as well as of thin, rhythmical sand-silt members. This rock sequence shows both gradational and convolute bedding. The blocks and smaller fragments of the diamictite are composed of granite, limestone, acid volcanics, and clastic rocks.

[23] Similar rocks of the Minor Karatau Ridge in the Talas Zone contains fragments of ophiolites suggesting the probable proximity of an oceanic basin. The accumulation of diamictite at the continental slope toward the oceanic basin and at the base of this continental slope seems to be most probable.

[24] The stratigraphic position of these rocks corresponds to the Vendian. They are overlain by Cambrian sediments.

[25] These data suggest that during the Vendian the Earth crust of the Syr Darya Terrain experienced extension and continental rifting. These processes resulted in the opening of an oceanic basin.
[26] Cambrian and Ordovician. The Early Paleozoic rocks are widespread in the region discussed. (Figure 3). The diamictite, dated Vendian, are overlain with a stratigraphic unconformity, recorded by a weathering crust, are overlain by a sequence of siliceous and carbonate rocks (Shortor, Baidamtal, Berkut, and other formations, ranging from $100 \mathrm{~m}$ to $1000 \mathrm{~m}$ in thickness). The siliceous rocks are represented by phthanite containing molybdenum and vanadium. They alternate with and are replaced along the strike by carbonaceous-argillaceous or siliceous-argillaceous shales. The upper part of the rock sequence includes siliceous rocks enriched in manganese and hematite. The deep-sea deposits dominate in the eastern part of the Naryn Zone, in the rock sequence of the Sarydjaz Ridge. In the western and middle parts of this zone the dominant rocks are shallow-sea carbonate rocks. The organic remains of these rocks were identified as Middle and Late Cambrian trilobites, Late Cambrian conodonts, and Early Ordovician and Llanvirnian graptolites and conodonts.

[27] Resting with a stratigraphic unconformity on the Middle Ordovician rocks and transgressively on the older deposits is a sequence of rhythmically bedded polymictic sandstones, siltstones, and shales with occasional limestone interbeds (Ichkebash, Sarydjaz, and other formations, totaling $1500 \mathrm{~m}$ in thickness). The rocks of this sequence contain Middle Ordovician, Caradocian, and Ashgillian brachiopods, nautiloids, and graptolites. These deposits had accumulated on the passive margin of the Syr Darya Early Paleozoic terrain. They are represented by the facies of the upper part of the continental slope and by the unsorted accumulations of its foot.

[28] Deformations. The small overthrust remnants, composed of the rocks of the ophiolite association, and of Middle Ordovician island-arc volcanics, occur in the Chaartash, Akshiyrak (eastern), and Sarydzhaz ridges. The folding intensity in the Vendian and Lower Paleozoic rocks varies from area to area in the Naryn Zone. The strikes of the large fold axes are parallel to the strike of the Terskey oceanic suture.

[29] The stratigraphic rock sequence, embracing the Vendian and Early Paleozoic rocks, do not show any distinct angular unconformities. Consequently, the rocks of the zone discussed were folded not earlier than Caradocian time. The stratigraphic relations of the rocks suggest the potential formation of the folds and overthrusts in the time interval from the Caradocian to the Middle Devonian. It seems natural to associate the overthrusting of the ophiolites and the folding of the rocks with the collision of the Syr Darya and Issyk Kul terrains in the Late Ordovician.

\section{Nalaqin Zone}

[30] This zone is the continuation of the Naryn Zone into the Eastern Tien Shan region. The basement of this zone is composed of crystalline schist and gneiss whose Sm-Nd, $\mathrm{U}-\mathrm{Pb}$, and $\mathrm{Rb}-\mathrm{Sr}$ ages vary from 2780 to 900 million years [Filatova and He, 2002; Gao et al., 1995]. These rocks are overlain by volcanogenic terrigenous deposits and marble 


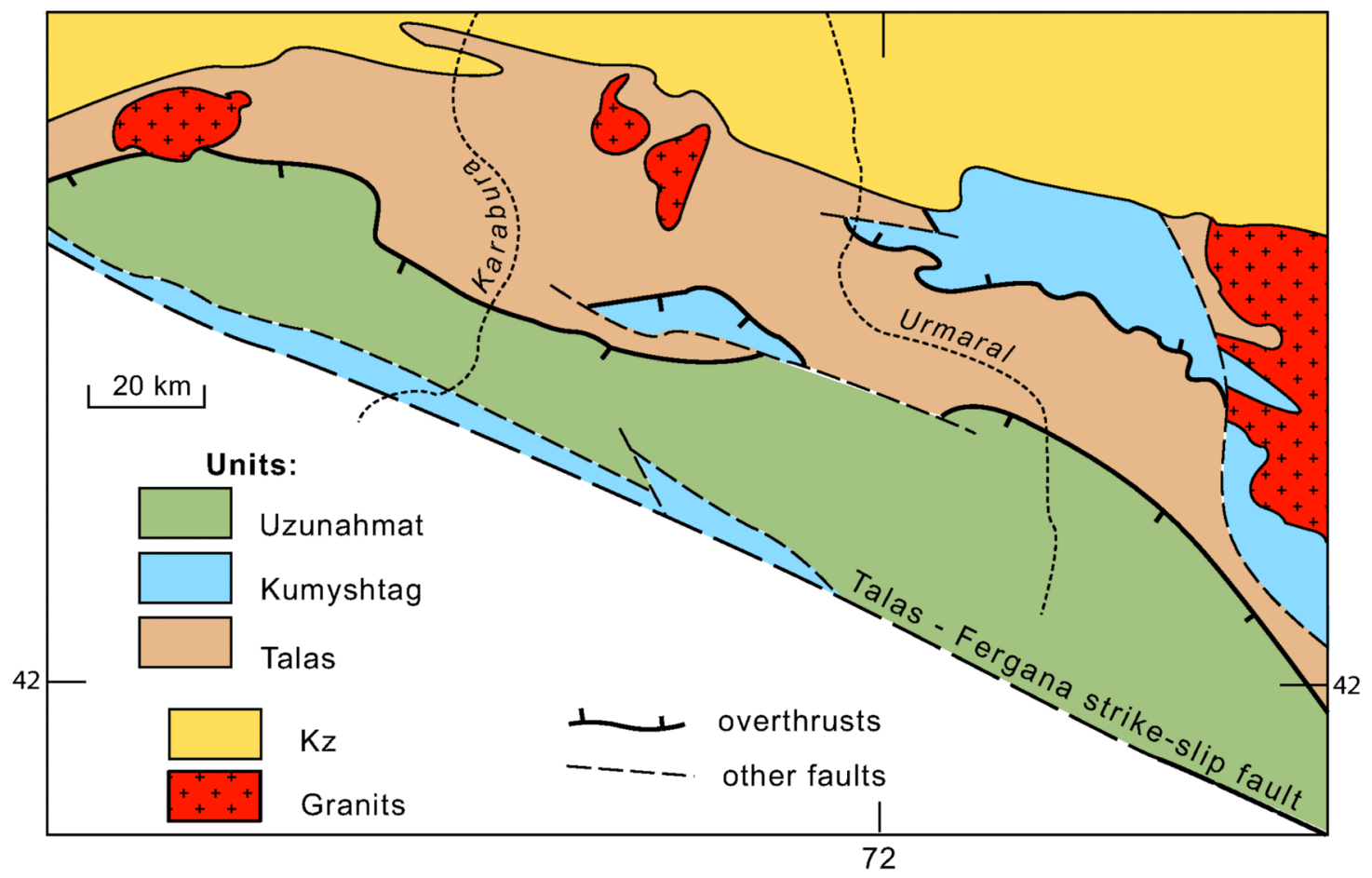

Figure 4. Structural units of the Talas tectonic zone at the northern slope of the Talas Ridge, after [Khudolei and Semiletkin, 1992; Klishevich and Semiletkin, 1995].

with Riphean stromatolites. The Riphean rocks are overlain unconformably by island arc volcanics, interbedded by Sinian diamictites. The intermediate and acid tuffs and lavas, apparently of Early Paleozoic age, are thrust over the Precambrian basement. These and Precambrian rocks are overlain by island-arc volcanics with Late Silurian corals in the limestone interbeds [Gao et al., 1998].

\section{Talas Zone}

[31] Widespread in this zone are the Sinian and Early Paleozoic rocks which occur as an assemblage of overthrust sheets [Alekseev, 1997; Khudolei and Semiletkin, 1992]. The geologic rock sequence shows the Talas, Kumyshtag and Uzunahmat structural units (Figure 4).

[32] Talas Unit. The basis of the visible rock sequence of this unit, outcropping in the Talas Ridge, includes a rhythmic rock sequence with thick $(20 \mathrm{~m}$ to $100 \mathrm{~m})$ rhythms of polymictic sandstone, siltstone, and shale. The rocks show gradational bedding, traces of sediment sliding, and signs of sea disturbance. The upper beds of this rock sequence include limestones with Late Precambrian microphytoliths (Sarydzhon and Tagyrtau formations, $2000 \mathrm{~m}$ thick). These rocks seem to be of Vendian age.

[33] These rocks are overlain conformably by carbonateterrigenous flysch (Chatkaragay and other formations, totaling $2000 \mathrm{~m}$ in thickness). The rhythmic units are composed of gravelite, calcareous sandstone and siltstone, calcareous shale, and limestone. Found in this rock sequence were Early Cambrian radiolarias, Cambrian chiolites, Tremadocian microfossils, and Ordovician-Silurian Chitinozoa. Middle Cambrian brachiopods were found in the Minor Karatau ridge, in the analog of this rock sequence.

[34] Kumyshtag Unit. In Sinian time coarse proximal flysch accumulated in the continental rift basin in the territory of the Minor Karatau Ridge. This process was interrupted by the epochs of the accumulation of fine-grained carbonate-terrigenous deposits and trachite, trachyliparite, trachyandesite, and dacite tuffs. Using the hieroglyphs available, the trend of the rock material transportation was found to be in the eastern and northeastern direction. The same trend was found for the replacement of coarse sediments by more thin and deeper rock material. In the similar deposits of the Talas Ridge, the U-Pb age of $680 \pm 20$ million years for the zircons from rhyolite and trachyrhyolite tuffs [Kiselev, 2001].

[35] The unilateral transportation of the terrigenous material into the basin discussed from the southwest (in modern coordinates) suggests the existence in the northeast of a riftorigin depocenter which hampered the flow of terrigenous material from the opposite edge of the basin. This continental rift preceded the opening of the Terskey oceanic basin, the rocks of the oceanic crust in which have a Cambrian and Ordovician age. 
[36] The Sinian rock sequence in the Minor Karatau Ridge is crowned by red and variegated unsorted conglomerates (Kengobysay and Ushbash formations, $200 \mathrm{~m}$ thick), which rest on the underlying rocks with a stratigraphic unconformity. Apart from the terrigenous material they contain pebbles of ultrabasic rocks, gabbro, and red chert. These conglomerates are overlain, with a stratigraphic break, by sediments with Tommotian (Early Cambrian) conodonts. The ophiolitic rocks composing the conglomerate pebbles suggest that a Terskey Basin with the oceanic crust had existed during the accumulation of the rock sequence discussed. Moreover, the rocks of the oceanic crust must have been partially deformed, abraded or eroded.

[37] In the Early Paleozoic carbonate sediments accumulated in the territory of the rock unit discussed at the passive margin of the oceanic basin. In the Minor Karatau Ridge the Tommotian Stage is represented by dolomites, phosphorites, and cherts with conodonts (Chulaktau Formation, $100 \mathrm{~m}$ thick). The Cambrian and Ordovician rocks contain various organic remains. The Middle Cambrian-Early Ordovician carbonate rocks are represented by their shallow-sea and relatively deeper rock varieties. The shallow-sea region had been situated in the southwest, while the deep-sea region had been located in the northeast of the region. The latter was filled with the clastic carbonate rock material, derived from the shallow-sea zone. In Llanvirnian time shallow-sea carbonate rocks accumulated. Later, the basin grew deeper, and during the Llandeilo time, the whole area happened to reside on the continental slope of the Syr Darya Terrain, where carbonate-terrigenous flysch (Zhyrykauz Formation, $500 \mathrm{~m}$ thick) accumulated. The shelf zone still existed in the area of the Talas Ridge, where shallow-sea carbonate sediments accumulated (Beshtash Formation, $2000 \mathrm{~m}$ thick). Atdabanian gastropods and chiolites were found in the lower part of these rocks, Lenian trilobites and brachiopods were found in the overlying rocks, and Early and Middle Ordovician trilobites and brachiopods were found in the upper rocks.

[38] Uzunahmat Unit. In the Talas Ridge this rock unit is composed of flysch which had experienced dynamic greenschist metamorphism. The rocks show the local traces of gradation layering. The lower part of this rock sequence has a carbonate-terrigenous composition, the upper being wholly terrigenous. No organic remains were found. The flysch has been supposedly dated Early Paleozoic.

[39] Deformations. The Early Paleozoic deformations took place in three stages, the earliest of them being of an overthrust type. The surfaces of the overthrusts separating the tectonic slabs are parallel to the layering in the hanging and lying limbs, irrespective of the dipping angle value. These are nappes which had been formed prior to folding. In the Minor Karatau Ridge, the Kumyshtag unit consists of several tectonic slabs, 1 to 4 kilometer thick. The transverse reduction of the initial area of this structural unit as a result of its overthrusting has been estimated to have been $100 \mathrm{~km}$.

[40] During the second deformation stage, these nappes were deformed to large folds with their axes striking to the northeast. Most of them are compressed folds with the cleavage of the axial surface. The transverse shortening of the area as a result of its folding has been estimated to be $30 \%$ for the Talas unit and 50-70\% for the Uzunahmat unit.

[41] The structural features of the third deformation stage cut across the structural features described above without involving the Early Carboniferous rocks. They occur as a system of conjugated faults, diagonal relative to the structural features of the second deformation stage. This system consists of left-handed shears of latitudinal trend and righthanded shear faults of meridional trend.

[42] The study of the relationships between the folds, cleavage, and metamorphic transformations of in the rocks of the Uzunahmat unit proved that the rocks had been metamorphosed before their folding.

[43] Deformation age. The lower age limit of the deformations was controlled by the Llandeilo-Caradocian age of the youngest rocks which experienced deformation in the Talas Zone. In the Minor Karatau Range the folded nappes had been cut by Late Ordovician granites, whose $\mathrm{Rb}-\mathrm{Sr}$ isochronous age was found to be $447 \pm 4$ million years, [Alekseev, 1997]. It follows that the rocks of the Talas zone were overthrust and folded in Late Ordovician time. These processes were caused by the collision of the Issyk Kul and Syr Darya microcontinents which took place at that time.

\subsection{Terskey Oceanic Basin}

[44] The rocks of the oceanic crust and oceanic island arcs occur in a broad band extending across the central Tien Shan from the western part of the Kirghiz Ridge to the eastern end of the Terskey Ridge. These rocks show tectonic relations with the surrounding rocks of the Issyk Kul Terrain. Some objects of study showed the allochthonous positions of the study rocks on the Lower Paleozoic rocks. In other cases the ophiolites were restricted by young faults or granite intrusions, where their allochthonous positions can be inferred. The oceanic basin, where these ophiolites are be the fragments of its crust, is referred to in the literature as the Terskey Basin, and also as the Terskey-Kenkol or as the Kirghiz-Terskey Basin.

[45] The Terskey Basin suture separates the rocks of the Syr Darya and Issyk Kul Early Paleozoic terrains. At the end of the Paleozoic the rocks of the Early Paleozoic Syr Darya Terrain and its Late Paleozoic cover had been thrust over the Issyk Kul Terrain and covered the Terskey oceanic suture. As a result, the suture line of the Terskey oceanic basin is marked on the earth surface by a system of late Paleozoic thrusts and strike-slip faults.

[46] The western segment of the ophiolite strip. The western segment of the Kirghiz Range includes the Karaarcha ophiolites (see 6 in Figure 3). They have tectonic contacts with the surrounding sedimentary and metamorphic rocks. The lower part of the ophiolite association is represented by pyroxenite, hornblendite, and a layered cumulate complex composed of pyroxenite and gabbroids, including olivine gabbro. The Ar-Ar age was determined for the leucocratic gabbro using clinopyroxene to be $480 \pm 4$ 
million years [Travin et al., 2002]. These rocks are metamorphozed to a green schist facies.

[47] These rocks are overlain by a thick sequence of tholeitic basalt, alkalic basalts, and basaltic andesites alternating with silicites. Widespread are pillow and amygdaloidal lavas. The upper part of this volcanic rock sequence includes significant amounts of lava breccias and tuffs. The different parts of this volcanic rock sequence include interlayers of siliceous rocks containing Late Cambrian and Lower and Middle Ordovician conodonts. The Ar-Ar age of the basalts, determined for their clinopyroxenes, was found to be $460 \pm 6$ million years [Travin et al., 2002]. The petrochemical characteristics of the rocks from the lower part of this rock sequence, dominated by alkaline rocks, suggest the intraplate environment, whereas the calc-alkalic basalts from the top of this rock sequence belong to an island-arc rock series. The spectra of the rare-earth and trace elements in the calc-alkalic basalts suggest that these basalts had been emplaced above the subduction zone [Lomize et al., 1997; Sakiev, 1991].

[48] Kenkol ophiolites (see 10 in Figure 3) occur as an extensive tectonic slab, clamped in the Early Paleozoic rocks at the southern slope of the Kirghiz Ridge and at the northern slope of the Talas Ridge. The tectonic lenses of serpentinite melange with gabbro and diabase blocks underlie a thick sequence of ball-shaped tholeitic basalt and basaltic andesite, as well as of basic tuff and jasper (Terek Formation, $2500 \mathrm{~m}$ thick). Found in the silicic rocks, interbedded in the volcanics, were Middle Cambrian algae, Late Cambrian conodonts, and radiolarians which were dated Early Ordovician and Llandeilo-Caradokian. Some of the petrochemical and geochemical characteristics of the lavas were found to correlate with those of some oceanic basalts (N-MORB), and others, with island-arc volcanics [Lomize et al., 1997].

[49] The small bodies of the Balachichkan ophiolites (see 3 in Figure 3) are exposed in the northern piedmont of the Talas Ridge. They are represented by pyroxenite, verlite, olivinite, websterite, and gabbroids. The ophiolites have tectonic relations with the Early Paleozoic sedimentary and metamorphic rocks and are cut by Late Ordovician and younger granites [Sakiev, 1991].

[50] At the northern slope of the Dzumgal Range a tectonic slab, $800 \mathrm{~m}$ thick, composed of serpentinite melange with large blocks of various rocks (Dzumgal Ophiolites, see 4 in Figure 3), occurs between the overthrust sheets composed of Early Paleozoic volcanogenic sediments. The blocks include pyroxenites, gabbro, a complex of parallel gabbrodiabase dikes, and the rocks of the neighboring tectonic slabs. The results of the structural study proved that the allochthons had moved from the south to the north in the modern coordinates [Hristov and Chernyshuk, 1987].

[51] The Toluk Ophiolites (see 12 in Figure 3) are located in the Susamyr Ridge. Here, the serpentinites have tectonic relations with gabbro and pillow-type tholeitic basalts, which compose the basic part of the ophiolite body cut by Late Ordovician granites. The basalts are petrochemically similar to the island arc lavas, their geochemical characteristics suggesting their accumulation during the early phase of the island arc development, or in the zone of back-arc spreading [Lomize et al., 1997].
[52] The Karakiche ophiolites (see 9 in Figure 3) in the eastern part of the Moldo Ridge are composed of serpentinite melange and peridotite, which are overlain by gabbro with swarms of parallel basalt dikes. Above follow pillow basalts whose geochemical characteristics suggest that they had composed the basis of the island arc or accumulated above the subduction zone [Lomize et al., 1997].

[53] The Karakatty ophiolites (see 8 in Figure 3), residing in the Karakatty Ridge, are thrust over the Lower Paleozoic limestones. The basis of this allochthon includes a serpentinite melange (1000 m thick) with blocks of peridotite, harzburgite, lherzolite, and volcanic rocks. This melange is overlain by several thick tectonic slabs. The lower overthrust sheet is composed of basalt and basaltic andesite tuff and tuffite and also of silicic schists with brachiopods, trilobites, gastropods, and nautiloids of Middle Ordovician age (Choloy Formation $2000 \mathrm{~m}$ thick). It appears that Middle Arenigian conodonts were identified in these rocks [Mikolaichuk et al., 1997], which verified their stratigraphic position. The petrochemical characteristics of the basalt fragments from the tuff breccias suggest their island-arc origin, the spectra of their rare and rare earth elements prove the existence of an oceanic island arc [Lomize et al., 1997]. The rocks of the upper part of the rock sequence include abundant terrigenous material, including rounded quartz grains. This suggests that the Arenigian time witnessed the collision between the oceanic island arc and the sialic block.

[54] These rocks are overlain by a tectonic slab composed of pillow tholeitic basalt with chert interlayers which were found to contain Late Cambrian conodonts (Karakatty Formation, $1000 \mathrm{~m}$ thick). Proceeding from their petrochemical characteristics and the presence of rare and rare earth elements of these rocks, the lavas can be ranked as N, T-MORB basalts [Lomize et al., 1997]. More higher is a gabbro overthrust sheet.

[55] Karadzorgo overthrust sheets and ophiolites (see 7 in Figure 3). The Karadzorgo Ridge includes a faulted and folded assemblage of overthrust sheets, including an ophiolite slab. The sequence of the overthrust sheets in the geologic section seems to be as follows [Kheraskova et al., 1997].

[56] The basis of the visible geological sequence is composed of tuffaceous turbidite with olistostrome layers. The limestone blocks of the latter contain Early Arenigian conodonts. These rocks are overlain by the first tectonic slab composed of limestone, calcarenite, and tuffaceous silicite with Late Cambrian-Early Tremadocian conodonts $(100 \mathrm{~m})$ and tephro-turbidites with Late Cambrian conodonts (Karadzorgo Formation, $800 \mathrm{~m}$ thick). These rocks are dominated by the proximal-facies turbidite. This tectonic slab is overlain by an olistostrome, which is overlain be the second tectonic slab.

[57] The lower part of the second slab is composed of limestone and a member of volcanic rocks (200 m thick), the alternating rocks of the latter being andesite, pillow basaltic andesite, and acid and basic tuffs. The top of this slab is composed of proximal tuff turbidites with Late CambrianTremadocian conodonts. These rocks had accumulated on the slopes and at the foot of the volcanoes, obviously belonging to an oceanic island arc.

[58] The third tectonic slab is composed of gabbro, gabbro- 
norite, pyroxenite with occasional dikes and swarms of parallel dikes [Mikolaichuk et al., 1997]. The study of the zonal spinels from the peridotites allowed the conclusion that these rocks had accumulated in the spreading zone, and were transformed later in the subduction zone [Demina et al., 1995]. It appears that these transformations took place in the island arc basement. The ophiolites are cut by Ordovician granites, most of them being separated by young faults from the Early Paleozoic sedimentary rocks. An ophiolite fragment, occurring as an allochthone, was found to be composed of serpentinite melange, tubular basalt, and hyalobasalt with chert interbeds. The chert blocks, residing in the melange, were found to contain Late Cambrian conodonts, Arenigian conodonts being found in the chert overlying the basalt [Kheraskova et al., 1997]. The ophiolites are thrust over by carbonaceous-siliceous shales with spicules of Cambrian sponges (Sokutash Formation).

[59] The upper part of the rock sequence described is composed of two Burenkhay nappes [Kheraskova et al., 1997]. The lower Burenkhay nappe is composed of volcanogenic terrigenous rocks of Riphean $\mathrm{U}-\mathrm{Pb}$ age. These rocks are siliceous shale, rhyolite, dacite, tuff, basaltic andesite, and basalt, identified as the Dzhilbulak, Ekurgenkol, and Belchi formations. The upper Burenkhay nappe is composed of metamorphic terrigenous rocks (Taragay Formation, $1000 \mathrm{~m}$ thick) and the overlying shelf limestones. Both of these tectonic slabs are cut by granites, whose $\mathrm{Pb}-\mathrm{Pb}$ age was found, using their zircons, to be 611-626 Ma [Mikolaichuk et al., 1997].

[60] The assemblage of the nappes of the Karadzorgo Ridge was formed in two stages. During the first stage in the Sinian time a package of two Burenkhay (now upper) nappes was formed. The most favorable condition for the origin of nappes is the formation of an accretionary prism in the oceanic margin or the collision of sialic blocks during the closure of the basin. Since the ophiolites are not included into the Burenkhay nappes, they seem to have been accumulated in the accretion prism. Consequently, it can be supposed that the Terskey oceanic basin had existed by the beginning of the Vendian with accretion processes operating at its margin. It is possible that these processes were operating in the island arc or at the Naryn (southern) margin of the Terskey oceanic basin, because the Burenkhay nappes rest higher than the nappes composed of crustal rocks of the Terskey oceanic basin.

[61] The second stage of the Karadzorgo overthrust nappe formation has been dated Early Ordovician. A system of nappes, including early Arenigian rocks, is sealed up by unconformable tuff conglomerates, tuff sandstones, and fine-grained tuffite with Arenigian-Llanvirnian graptolites [Kheraskova et al., 1997]. These relationships suggest that the oceanic arc collided with the passive margin of the Issyk Kul Terrain in Arenigian time.

[62] The Eastern Segment of the Ophiolite Band. The Kapkatash-Dzhetymbel ophiolites (see 5 in Figure 3) are represented in the mountains of the same name by serpentinized dunite, gabbroids, and volcanic rocks which have fault contacts with the ultrabasic rocks and gabbro. The volcanic part of this rock association is composed of massive pillow and tubular basalts, interbedded by tuff conglomerates, limestones, and cherts with spicules of Early Paleozoic sponges (Beltepshi Formation, $1000 \mathrm{~m}$ thick). Proceeding from their petrologic and geochemical characteristics, the basalts have been classified as island-arc tholeiites [Ges, 1999; Lomize et al., 1997]. The higher rock sequence is composed of basalt, andesite, dacite, rhyolite, and their tuffs with interbeds of tuffaceous sandstones and limestones with trilobites, brachiopods, gastropods, ostracodes, and conodonts of the Lower Cambrian Botomian stage (Sultansary and Techar formations, $2000 \mathrm{~m}$ thick). These rocks are overlain by dacite and rhyolite tuffs, tuffaceous sandstones and siltstones with Late Cambrian conodonts in the limestone interbeds.

[63] The Tegerek ophiolite-clastic rock olistostrome (see 11 in Figure 3) is exposed in the northwestern piedmont of the Terskey Ridge. It consists of the blocks composed of serpentinite, pyroxenite, massive and cumulative gabbro, and other rocks of ophiolite association in carbonate cement. These rocks compose several tectonic slabs totaling more than $1000 \mathrm{~m}$ in thickness. The ophiolite saturation of this olistostrome and the size of the olistoliths grow upward. The olistostrome rests on the Sinian quartz sandstones.

[64] The Ashuldebe (see 1 in Figure 3) and Turgeniaksu (see 13 in Figure 3) basalts occur in the middle and eastern parts of the Terskey Ridge in the form of tectonic blocks. The basalts have a pillow structure and alternate with tuff, tuffite, and siliceous rocks. The rock sequence includes rhyolite and dacite flows and acid tuff interlayers. Cambrian to Ordovician radiolarians were identified in the chert of the Terskey Formation, $1500 \mathrm{~m}$ thick. Above follows a sequence (1000 m thick) of tuffaceous sandstone and tuff with jasper interlayers, which contain Early Paleozoic radiolarias and sponge spicules.

[65] The Ashuturuk basalts (see 2 in Figure 3) are exposed at the eastern end of the Terskey Ridge. The pillow and massive basalts include conglomerate, chert, and marble interlayers with Early and Middle Cambrian radiolarias. The basalts are overlain by a sequence of andesite-basalt hyalotuffs, acid tuffs, tuff conglomerates, tuffaceous sandstones, cherts, and limestones. All of these rocks have tectonic relations with the surrounding deposits.

[66] All of these rocks had been overthrust on the Issyk Kul Terrain. Their root zone is located in the suture of the Terskey Early Paleozoic oceanic basin.

[67] Small overthrust remnants, composed of the rocks of the ophiolite association and of Middle Ordovician islandarc volcanics, are known also in the Naryn Zone of the Syr Darya terrain, namely, in the Chaartash, Eastern Akshiyrak, and Sarydjaz ridges. They rest on the Early Paleozoic rocks. Their root zone and the directions of their motion are still unknown. The structural positions of their klippens suggest their origin both from the Terskey and Turkestan oceanic basins.

\section{Karadzorgo Oceanic Island Arc}

[68] Most of the ophiolitic allochthons are associated with island-arc volcanics and seem to be the rocks of 


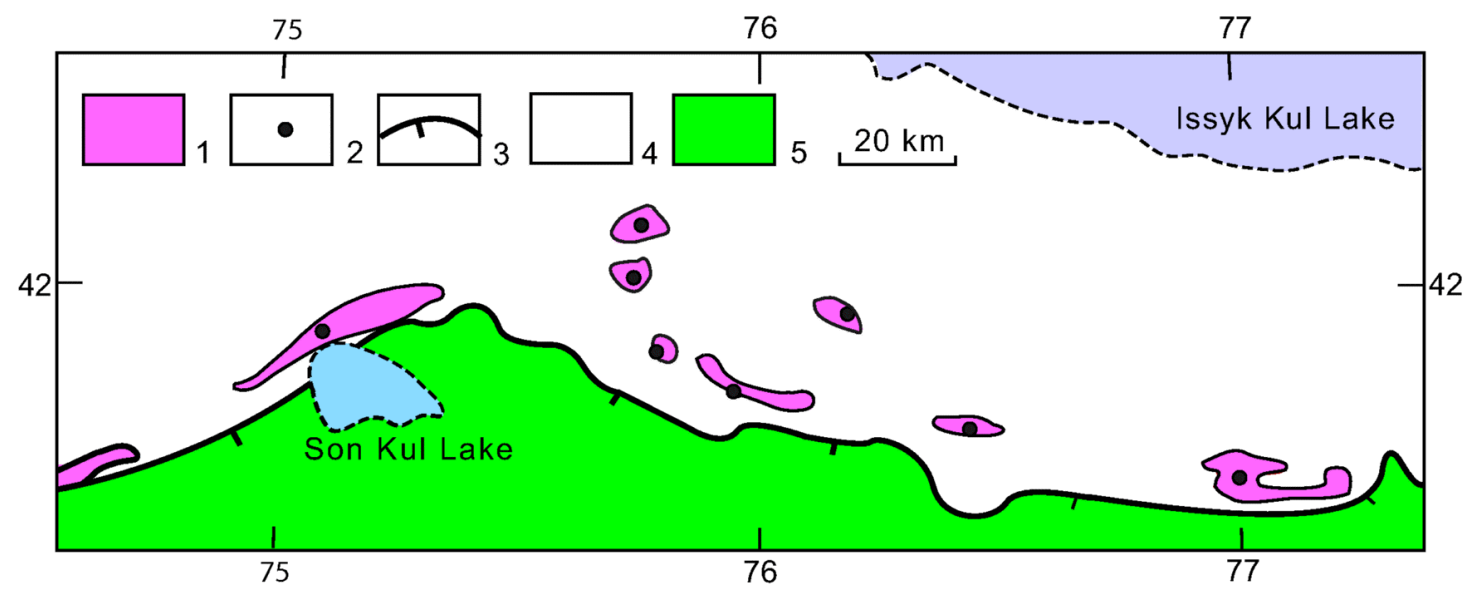

Figure 5. Early Ordovician granitoids in the western segment of the Terskey Ridge and in the area of the Son Kul Lake, after [Mikolaichuk et al., 1997]: (1) Early Ordovician subduction-type granitoids intruded into the rocks of the oceanic island arc; $(2)$ the sites of collecting samples, whose zircons were used to estimate the $\mathrm{U}-\mathrm{Pb}$ and $\mathrm{Pb}-\mathrm{Pb}$ ages of the rocks in the interval of 500-470 million years; (3) the Late Paleozoic overthrust, known as the "Nikolaev Line"; (4) Issyk Kul Terrain; (5) Syr Darya Terrain.

oceanic island-arc basement. This suggests that during the Cambrian-Early Ordovician an oceanic volcanic island arc or, most probably, an assemblage of such island arcs existed in the Terskey Basin. This island arc assemblage is known in the literature as a Karadzorgo island arc (and also as the Kapkatash, Sarybulak, Choloy, and East Terskey island arc).

[69] The rocks of the Karadzorgo oceanic island arc are cut by the small masses of Early Ordovician granites whose $\mathrm{U}-\mathrm{Pb}$ and $\mathrm{Pb}-\mathrm{Pb}$ ages determined for their zircons fall within the time interval of 500-470 million years (Figure 5). These rocks are quartz diorite, granodiorite, as well as quartz monzonite and quartz syenite cutting the former. These granitoids cut the rocks of the ophiolite basement of the island arc, the Cambrian-Lower Ordovician island-arc volcanics, and the terrigenous carbonate rocks of the arc slopes [Mikolaichuk et al., 1997]. The petrochemical and geochemical properties of these granites agree with those of $\mathrm{M}$ type granitoids [Ges, 1999].

[70] The Karadzorgo oceanic island arc divided the Terskey oceanic basin into the Naryn back arc and the Kensay forearc basins. The ocean-floor sediments of the Kensay basin have been preserved in the Ichkele Ridge, where variegated argillites, sandstones, and siltstones with Arenigian graptolites include chert, limestone, and turbidite interlayers, this total rocks sequence being known as the Kensay Formation, $1000 \mathrm{~m}$ thick. The sandstone lithology suggests the presence of two sources of rock material. One of them was the Karadzorgo island arc which supplied volcanic rock fragments. The other source of removed rock material was the Issyk Kul microcontinent, which supplied quartz, plagioclase, and mica, as well as quartzite and granite fragments [Maksumova, 1999]. These deposits seem to have accumulated during the late epoch of the existence of the Kensay forearc basin before its closure.

\subsection{Issyk Kul Terrain.}

[71] The rocks of the Early Paleozoic Issyk Kul Terrain are widespread in the areas of the Central and Eastern Tien Shan (Figure 3). This terrain is a kingdom of Paleozoic granites. Its sedimentary and volcanic rocks occur as fragments of the geologic and stratigraphic sequences of the rocks which had been deformed and experienced the significant effects of intrusions.

[72] Basement. The basement of this terrain is composed of repeatedly metamorphosed rocks which had been brought to the ground surface in the Kirghiz, Kendyktas, Kastek, Transili, Kungey, and Terskey ridges. The isotopic ages of $2.2-1.6$ billion years were obtained for these rocks using the $\mathrm{U}-\mathrm{Pb}$ method for zircons from the Kirghiz and Transili ridges [Kiselev et al., 1993].

[73] Riphean. The Riphean rocks, which were dated, using their stromatolites and an alpha-lead method, occur in the western segment of the Kirghiz Range, composed of quartz sandstones, conglomerates, and limestones, which had accumulated in a shallow continental sea (Ortotau Formation, $3000 \mathrm{~m}$ thick).

[74] The Riphean rocks of this type occur at the southern slope of the Terskey Range. Their visible sequence begins with carbonaceous argillite and siltstone, containing acid pyroclastic material. These rocks are followed upward by a sequence of metamorphosed rhyolite, dacite, tuff, and tuffite, which is overlain by basaltic andesite and basalt (Dzhilbulak, Ekurgenkol, and Belchi formations, $2000 \mathrm{~m}$ thick). The $\mathrm{Pb}-\mathrm{Pb}$ ages of the zircons from the acid lavas were dated $1380 \mathrm{Ma}$ and $1090 \mathrm{Ma}$. The petrochemical composition of the basic lavas suggests them to be high-Ti intraplate basalts. Combined with the antidrome structure of this rock 
sequence, these data prove that these rocks had accumulated in a continental rift [Kiselev et al., 1993; Mikolaichuk et al., 1997]. It appears that accumulated under the same conditions were the volcanic and terrigenous rocks in the eastern part of the Issyk Kul Terrain, in the Kawabulak Mountains, located south of the Turfan Basin. The zircons from these rocks have $\mathrm{U}-\mathrm{Pb}$ ages ranging $1350 \mathrm{Ma}$ to $950 \mathrm{MA}$ [Filatova and $\mathrm{He}, 2002]$.

[75] The U-Pb ages of the Riphean interval were obtained for some granites from the Kirghiz, Susamyr, Kungey, and Terskey ridges [Kiselev, 1999].

[76] Sinian. The gneisses and migmatites of the Kungey Ridge are overlain by acid effusive rocks (Karakorum Formation), whose $\mathrm{Pb}-\mathrm{Pb}$ ages of the zircons were found to be in the range of 740-840 Ma [Mikolaichuk, 1998]. The western segment of the Kirghiz Ridge is composed of quartz sandstone and thin-layered limestone with chert nodules and Sinian microphytoliths (Uchkoshoy Formation, $1500 \mathrm{~m}$ thick). Similar deposits are widespread in the Eastern segment of the Talas Ridge, where stromatolites and microphytoliths, typical of the Sinian, were collected. Found in the Terskey Ridge were granodiorites and diorites, whose U-Pb ages corresponded to the Vendian [Kiselev et al., 1993].

\section{Cambrian and Ordovician}

[77] The Cambrian and Early Ordovician sedimentary rocks accumulated on the Terskey and Ilian passive margins of the Issyk Kul Terrain. During the Middle Ordovician, marginal igneous rock belts and intracontinental sedimentation basins originated in this terrain.

[78] Sedimentary rocks of the Terskey Margin. Prior to the Ordovician, the southern margin of the Issyk Kul Terrain, facing the Terskey oceanic basin, had been a passive one. Terrigenous deposits accumulated on the continental slope, carbonate deposits dominating in the shelf area (Figure 3).

[79] Shelf. The western segment of the Kirghiz Ridge includes a rock sequence dominated by limestone, sandstone, tuff, and tuffite with Middle and Late Cambrian trilobites (Kotudzhan Formation, $600 \mathrm{~m}$ thick). Dominating at the southern slope of this ridge are limestones alternating with carbonate shale (Tersbutak and other formations, $1500 \mathrm{~m}$ thick). These shales contain sponge spicules and radial cyatholiths which date them Early Paleozoic. Widespread in the Ichkele Ridge is a sequence of limestones, partially clastic, algal, and oolitic, with Arenigian-Llanvirnian graptolites in the top of the rock sequence, known as the Ailyampatau Formation, $1000 \mathrm{~m}$ thick.

[80] Exposed at the northern slope of the Susamyr Ridge are green and gray calcareous conglomerates, sandstones, siltstones, and siliceous-argilaceous rocks with tuff and tuffite interlayers, and Middle Ordovician brachiopods, trilobites, and graptolites (Dzhaisan Formation, 1000 m thick). Resting unconformably on these rocks are conglomerates and tuffaceous conglomerates, which are placed upward by a rhythmic alternation of sandstones and siltstones containing Middle
Ordovician bryozoans, trilobites, and nautiloids (Muztor Formation, $1000 \mathrm{~m}$ thick).

[81] In the western and central segments of the Terskey Ridge the thin-bedded siltstones and quartz sandstones are overlain by a thick sequence of limestones (Suek and Taldysu formations, $2000 \mathrm{~m}$ thick). These deposits are cut by granites, the Middle Ordovician radiometric age of which marks the upper limit of sediment accumulation. The eastern segment of this ridge includes a thick sequence of alternating carbonaceous shales and limestones (Ashuairyk Formation, $1500 \mathrm{~m}$ thick). The organic remains found in the rocks of both formations suggest the Early Paleozoic age.

[82] Continental slope and its pedestal. The tectonic sheets of the Ichkele Ridge include a sequence of carbonaceous argillites, siltstones, quartz sandstones, and radiolarites with molds of fine ripple marks and thin cross-bedding, characteristic of contour currents. There are coarse-clastic rocks with fragments of shallow-sea limestones and sandstones, which were emplaced as a result of landslides and gravitational flows. The amount of coarse-clastic rocks grows toward the top of the rock sequence, the typical example being the Akterek Formation, where the Arenigian graptolites and Llanvirnian brachiopods were collected.

[83] In the Dzumgal Ridge the continental slope rocks are in allochthonous position. The lower part of their visible sequence includes a rock sequence with alternating members of conglomerate breccias, turbidites, olistostromes, and cherts (Aktoy and other formations, $2000 \mathrm{~m}$ thick). The conglomerates breccias consist of limestone, gabbro, basalt, andesite, diorite, and basic tuff fragments. The turbidites consist of tuff sandstones and siltstones with gradational cross-bedding. The olistostromes include limestone olistoliths with Middle Cambrian brachiopods. The top of this rock sequence is dominated by graywacke turbidites with some arkose rocks. This suggests the existence of two sources of the rock material, namely, the volcanic arc and the continent. Found in the turbidites were Arenigian-Llanvirnean graptolites, Early Ordovician and Late Llandeilian-Early Caradocian conodonts, and Middle Ordovician radiolarians. The accumulation of the lower part of this rocks sequence seems to have occurred at the foot of the continental slope. The turbidites of the upper part of this rock sequence, which derived their source material from the island arc and the continent record the onset of the collision of this island arc with the continent.

[84] Widespread in the area of the Son Kul Lake are Middle Ordovician terrigenous flysch deposits, known as the Dolon, Djoldjilga, and other formations, $2500 \mathrm{~m}$ thick. In the Karadzorgo Ridge they rest, with an angular unconformity, on the Late Cambrian-Early Ordovician rocks which had composed an accretionary prism that had originated in Arenigian time. Resting at the base of this rock sequence are conglomerates with pebbles of the underlying volcanic rocks and blocks of shelf limestone containing Late Cambrian-Early Tremodokian conodonts. The siltstone cement of the conglomerates contains Ordovician graptolites. The conglomerates are overlain by a sequence of distal turbidite with Arenigian conodonts and graptolites, dating the rocks Middle and Late Arenigian. This rock sequence is followed by a proximal turbidite sequence, consisting 
of rhythmically alternating conglomerates, gravelites, and sandstones. The siliceous shale interbeds contain Early and Middle Llanvirnian graptolites and some depressed forms of trilobites. Along the strike the proximal turbidites grade to pudding stones and conglomerates with pebbles and boulders of limestone, sandstone, and volcanic rocks. The upper rock sequence (Dzhakshin Formation, $800 \mathrm{~m}$ thick) is composed of dacite and andesite-dacite tuff, variegated siltstones, and quartz sandstones with Llanvirnian-Caradocian graptolites.

[85] Exposed at the northern slope of the Moldo Ridge are Late Ordovician terrigenous rocks which seem to continue the rock sequence described above. This thick rock sequence is composed of sandstones and siltstones with oolitic limestone interbeds (Tabylgaty Formation, $2000 \mathrm{~m}$ thick). In the upper part of this rock sequence, the rocks are red and cross-bedded and include conglomerates with quartz pebbles. The graptolites and brachiopods studied in many rock intervals proved the lower part of this rock sequence to be Middle Llandeilian, and the upper rocks to be Early and Late Caradocian.

[86] The sequence of the Middle-Late Ordovician rocks described in the area of the Son Kul Lake proves the evolution of the sedimentation conditions from the continental foot and lower continental slope (Middle and Late Arenigian) to the upper part of the continental slope (Middle Ordovician) and to the coastal conditions, including the alluvial ones (Karadokian).

[87] A tectonic block in the middle of the Terskey Ridge preserved a sequence of proximal turbidite with Middle Ordovician brachiopods. Up the sequence, the turbidites are replaced by quartz sandstones and conglomerates (Arabel Formation, $1300 \mathrm{~m}$ thick).

[88] Sedimentary deposits in the Ili margin. In Cambrian time the Ili margin of the Issyk Kul Terrain (northern margin in the present-day conditions) was passive, similar to the Terskey margin. In the Kungey Ridge the Late Riphean-Early Sinian gneisses were overlain transgressively, by conglomerates at the base, by quartz sandstones, carbonaceous shales, and shallow-sea limestones with Cambrian sponge spicules and acritarches (Toraigyr Formation, $1000 \mathrm{~m}$ thick). The higher stratigraphic position is occupied by a rhythmic sequence of volcanomictic and polymictic sandstones, siltstones, and siliceous tuffite with hierogliths, cross-bedding, sediment sliding traces, ripple marks, and desiccation cracks. Found in these rocks were Early Tremadocian graptolites and brachiopods (Cholponata Formation, $1500 \mathrm{~m}$ thick). These rocks are overlain unconformably, with conglomerates at the basis, by algal and organoclastic limestones with Early Ordovician brachiopods (Dolonaty Formation, $100 \mathrm{~m}$ thick) which are overlain conformably by silty shales with Late Arenigian graptolites. Widespread at the northern slope of the Kungey Ridge is a rhythmic sequence of calcareous conglomerates, sandstones, and siltstones with Llanvirnian and Llandeilo brachiopods, trilobites, and graptolites.

[89] Known in the Kastek Ridge are the outcrops of conglomerates and sandstones with Atdabanian conodonts, and algal limestones which are overlain conformably by chert and bedded limestones with Late Cambrian conodonts, trilobites, and brachiopods (Karagaily Formation, $300 \mathrm{~m}$ thick). During the Ordovician, the territory of the Kostek Ridge included a carbonate reef surrounded by a coarse flysch with limestone fragments (Kartabulgi Formation, $1000 \mathrm{~m}$ thick). The lower reef rocks contain Early Ordovician conodonts, followed upward by Middle Ordovician trilobites and conodonts, and also by algae, brachiopods, gastropods, and crinoids. Llanvirnian graptolites were found in the flysch.

[90] Widespread in the Kendyktas Ridge are sandstones and shales with interbeds of conglomerates, carbonaceous shale, chert, phosphorite, and limestone with Middle and Late Cambrian trilobites and brachiopods (Zhaisan Formation, $3000 \mathrm{~m}$ thick), and a sequence of terrigenous flysch whose brachiopods suggest the age interval of the rocks to be within Cambrian and Tremadocian (Dzhambul Formation $2000 \mathrm{~m}$ thick). The higher position in the stratigraphic sequence is occupied by cross-bedded quartz sandstone, siltstone, argillite, and limestone with Tremadocian, Arenigian and Llanvirnian trilobites, brachiopods, gastropods, and graptolites (Kendyktas, Agalatas, Kurdai, and Shcherbakty formations, $2500 \mathrm{~m}$ thick).

[91] In the eastern segments of the Transili and Kungey ridges the middle Ordovician rocks and transgressively the older rocks are overlain by sandstones and conglomerates with limestone interbeds which contain Caradocian brachiopods, pelecypods, gastropods, and trilobites (1000 m).

[92] Sedimentary rocks of intracontinental basins. At the end of the Early and during the Middle Ordovician internal basins originated in the Issyk Kul Terrain. Thick sequences of clastic rocks accumulated in the basins of this kind (Figure 3). Occurring at the western end of the Kirghiz Ridge is a sequence of quartz, arkose, polymictic and tuffaceous, coarse-grained sandstones and siltstones, partially cross-bedded, with the interbeds of conglomerates and limestones with Middle and Late Ordovician brachiopods, trilobites, and graptolites (Tekturmas, Almaly, Karasai, and other formations, totaling $5000 \mathrm{~m}$ in thickness).

[93] Widespread in the central segment of the Kirghiz Ridge are Middle Ordovician terrigenous deposits (the Karabalty, Chonkaindy, and Dzhartash formations totaling $7000 \mathrm{~m}$ in thickness). The lower part of the visible rock sequence is composed of massive and thin-bedded siltstones and fine-grained sandstones with argillite interbeds and limestone lenses. Found in this rock sequence were Llanvirnian trilobites and Llandeilian graptolites, and also Llandeilian brachiopods found in the vicinity of its top. These rocks are overlain unconformably, with conglomerates at their basis, by polymictic and quartz-feldspathic, mostly red sandstones and siltstones, interbedded by oolitic limestones. This rock sequence includes many cross-bedded members and shows occasional imprints of ripple and rain drop marks, as well as traces of sediment drying and cracking. Found in this part of the rock sequence were Llanvirnian conodonts. Conformably following above is a sequence of thin-bedded carbonaceous and argilaceous siltstones and limestones including quartz sandstone interbeds. Found in these rocks were Llandeilian conodonts. Different parts of this rock sequence include occasional interbeds of acid and intermediate tuff and lava, 
including those of trachyandesite. The composition and structure of these sediments suggest the evolution of the sediment accumulation conditions from those of piedmont or graben to shallow-sea and delta conditions and further to anaerobic sedimentation ones [Hristov and Shilov, 1998].

[94] The southern slope of the Susamyr Ridge includes red and variegated clastic rocks (1000 m thick) with Early and Middle Caradocian brachiopods. A sequence of red and variegated sandstones and siltstones (800 m thick) with Late Ordovician brachiopods is exposed on the northern slope of the Transili Ridge. Widespread at the eastern end of this ridge are red conglomerates, sandstones, siltstones, argillites, and limestones with Ashgilian trilobites, gastropods, and brachiopods (Syugaty Formation, $1000 \mathrm{~m}$ thick). Variegated clastic rocks and shales with Caradocian mollusks are also known in the eastern segment of the Kungey Ridge.

[95] Volcanogenic sediments. In the area of the Issyk Kul Terrain the products of subduction magmatism are of Ordovician age. Volcanic rocks are limited, the Ordovician subduction granites being more widely developed (Figure 3). The Ordovician volcanics tend to be located in the Terskey and Ili margins of the Issyk Kul Terrain.

[96] The rocks of the Terskey areal are wide-spread in the western segment of the Kirghiz Range and also in the Susamyr Mountain Range. Exposed in the Kirghiz Range are the rocks of the Keptash, Barkol and Utmek formations and have a thickness of $5000 \mathrm{~m}$. The basis of this rock sequence is composed of polymictic sandstones, siltstones, tuffaceous sandstones, and ash tuff. These rocks are interbedded with andesites and limestones containing brachiopods, cephalopods, trilobites, and gastropods of EarlyMiddle Ordovician age. The upper part of this rock sequence is more saturated by volcanic rocks, namely, by andesite, dacite, and their tuffs, the ages of the latter being less definite. Reported in the literature are the findings of Late Ordovician sponges in them. Nautiloids and bryozoans of Middle-Late Ordovician age are believed to have been found in this part of the rock sequence in the northern part of the Susamyr Ridge.

[97] Widespread in the southern part of the Susamyr Ridge are Middle-Late Ordovician terrigenous and volcanogenic sedimentary rocks (Toluk Formation, $2000 \mathrm{~m}$ thick). The lower part of the visible rock sequence is composed of siltstones and sandstones with quartz and feldspar grains, and also with sandstone and effusive rock fragments. The siltstones contain graptolites of the Llanvirnean stage. These rocks are followed conformably by $500 \mathrm{~m}$ of andesite clastic lavas, which alternate with dacites, rhyolite dacites, tuff sandstones, and siltstones containing Early Llandeilo graptolites and Caradocian brachiopods. These lavas are overlain by gray sandstones and siltstones, which are followed conformably upward by a sequence of red and variegated clastic rocks. The latter contain Early and Middle Caradocian brachiopods.

[98] The rocks of the Ili areal are exposed at the eastern end of the Kirghiz Ridge and in the Kendyktas, Kastek, Transili, Kungey, and Ketmen ridges. Developed in the eastern segment of the Kirghiz Range are andesites, tuff-breccias, and tuffs interbedded by siliceous shale, sandstone, and lime- stone with Middle Ordovician brachiopods and foraminifers (Oktorkoi Formation, $1500 \mathrm{~m}$ thick). In the Kendyktas Ridge, the rocks with Llanvirnian graptolites are overlain conformably by a rock sequence composed of andesite, its tuff, tuff-sandstones, tuff conglomerates, sandstones, and siltstones with limestone interbeds. Found in the latter were Landeilian and Caradician brachiopods and trilobites (Rgaity and Keskintas formations, $2500 \mathrm{~m}$ thick).

[99] At the northern slope of the Kungey Ridge the effusive rocks of intermediate and basic composition occur as interbeds in the volcanic flysch containing Early Tremadocian graptolites and brachiopods. In the same area the rocks with Llanvirnian graptolites are overlain with a stratigraphic unconformity by andesite and basaltic andesite lavas, volcanic breccias, tuff conglomerates, tuff sandstones, and cherts (Koksu Formation, $500 \mathrm{~m}$ thick). A trilobite of Caradocian age was identified in a limestone fragment from this (?) rock sequence. Lying at the southern slope of the Transili Ridge is a sequence of tuffaceous siltstones, sandstones, and conglomerates $(2000 \mathrm{~m})$, partly cross-bedded, containing Tremadocian, Arenigian, and Llandeilo trilobites.

[100] Developed in the Kastek and Ketmen ranges are basalts, andesitic basalts, tuffs, tuffaceous sandstones and limestones (Kuturgan Formation, $1000 \mathrm{~m}$ thick) with Llanvirnian and Early Caradocian brachiopods and trilobites.

[101] Early Paleozoic rocks are not known in the West Xinjiang at the extension of the Issyk Kul Terrain. They seem to have not been separated from the Precambrian rock complexes. The most eastern part of the Issyk Kul Terrain occurs south of the Turfan Basin. Exposed there in the Kawabulak Mountains are Lower Cambrian-Middle Ordovician rocks, represented by cherts with radiolaria, sandstones, siltstones, and limestones with tuff interbeds in the Middle Ordovician rocks [Filatova and He, 2002; Hsu et al., 1994; Hu et al., 2000].

[102] Granitoids. During the Ordovician-Early Silurian large masses of granitoids were intruded into the Terskey Ridge and west of it. Their $\mathrm{U}-\mathrm{Pb}$ and $\mathrm{Pb}-\mathrm{Pb}$ ages were dated 465-435 million years, using their zircons. These rocks were classified as granites, granodiorites, quartz diorites, and quartz monzonites. These are usually multiphase intrusions, their later phases having a more acid composition. Judging by their petrochemistry and mineralogy, they include subduction granites of the I-type (Figure 3) and collision granites of the S-type (Figure 6). The earlier diorites, monzonites, and granodiorites were ranked as I-type, the later granodiorites and granites, as S-type [Ges, 1999; Jenchuraeva et al., 2001].

[103] The subduction granites of the I-type, dated Middle Ordovician or Middle-Late Ordovician, occur as two marginal igneous rock belts of Andean type. The Southern (Terskey) Belt extends along the Terskey and Kirghiz ridges, north of the Terskey oceanic basin suture. The formation of this belt granitoids was caused by the subduction of the Terskey Basin crust. The U-Pb isochronous age of $464 \pm 2$ million years was obtained for granodiorites from a small granodiorite, quartz monzonite, granite massif located at the western end of the Kirghiz Ridge [Kiselev, 1999]. The upper age limit 


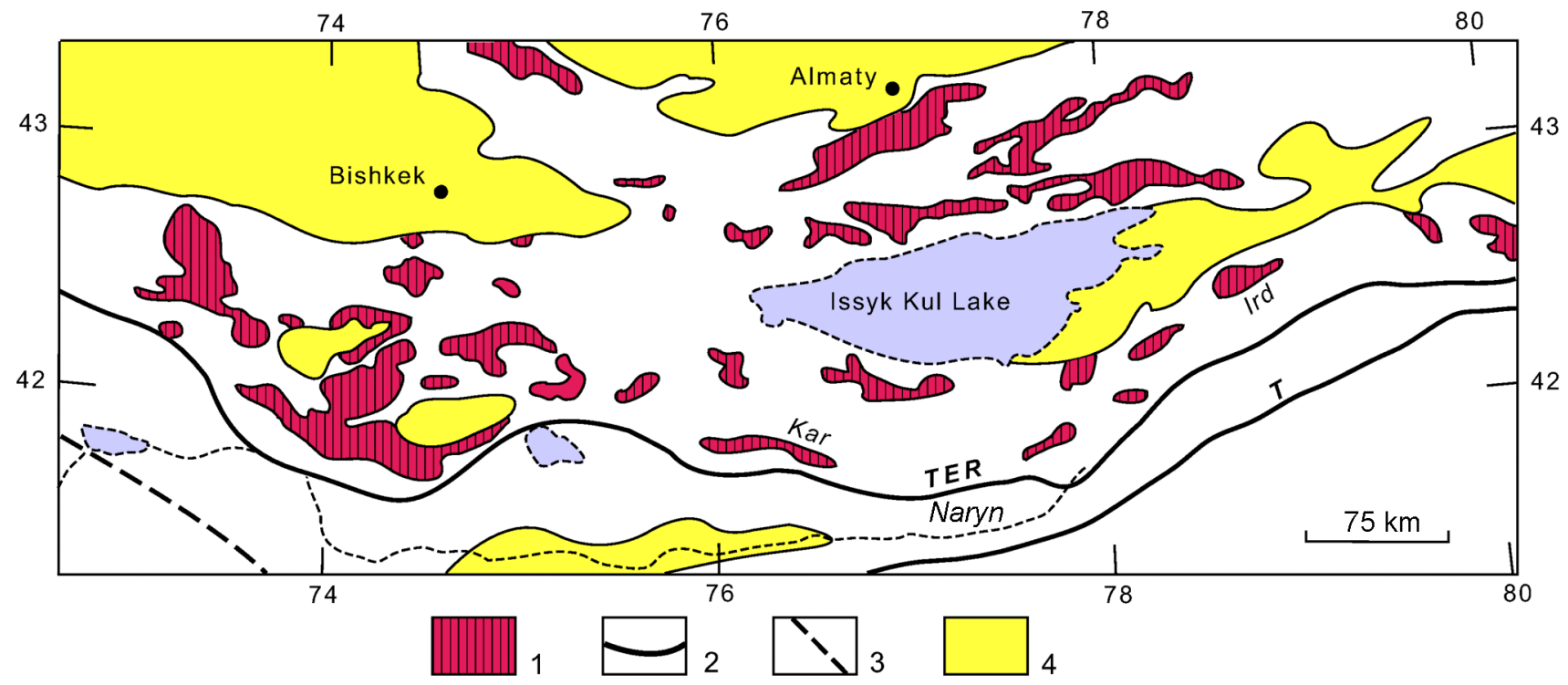

Figure 6. Late Ordovician-Silurian granitoids in the Issyk Kul Terrain: (1) Late Ordovician and Silurian S-type granitoids (Irdyk (Ird) and Karakudzhur (Kar) granite massifs), (2) Sutures of the Terskey (TER) and Turkestan (T) oceanic basins, (3) Talas-Fergana strike-slip fault, (4) Cenozoic basins.

for the formation of this intrusion was dated using the stratigraphic superposition of the rocks with Middle Ordovician graptolites and brachiopods. Also Middle Ordovician are the tonolites and granodiorites of the Aspara Massif (see A in Figure 3) residing in the middle segment of the Kirghiz Ridge, which are overlain transgressively, with conglomerates at the base, by the Middle and Upper Ordovician rocks. The other granite massifs of this kind were dated relying on the radiometric data available [Kiselev, 1999].

[104] The intrusion of the granite massifs of the northern (Transili) marginal igneous-rock belt, which are located in the area of the Transili and Kungey ridges, seems to have been associated with the subduction from the Ili oceanic basin. In the Transili Ridge these granitoids are overlain by red clastic rocks with Ashgillian fauna.

[105] S-type granitoids are widespread in the Issyk Kul Terrain (Figure 6). They cut the Late Odovician rocks and I-type granitoids. The age interval of the S-type granites embraces the Late Ordovician and Silurian. The U-Pb isochronous age interval of 433-437 million years was obtained for the granodiorites of the Karakudzhur (Kar in Fig. 6), Irdyk (Ird in Figure 6), and some other rock massifs in the Terskey Ridge [Kiselev, 1999].

[106] Deformations. The Early Paleozoic deformations at the margins and in the middle of the Issyk Kul microcontinent differ substantially. At the end of the middle or at the beginning of the Late Ordovician, the rocks of the Karadzorgo oceanic island arc were thrust over the deposits of the continental slope and shelf of the Terskey margin of the Issyk Kul microcontinent, while the ophiolitic tectonic nappes were thrust over the rocks of this island arc, over the deposits of the Issyk Kul microcontinent margin, and over the rocks of its basement. Later, all of these rocks were folded.
[107] A similar situation existed at the Ili margin of the Issyk Kul Terrain, where the Kungey sequence of Early Paleozoic andesitic basalts rests as an overthrust sheet on the shelf limestones of the same age [Mikolaichuk, 1998]. The roots of this nappe seem to be located in the zone of the Ili oceanic suture.

[108] The Early Paleozoic rocks of the Issyk Kul Terrain are folded. Dominating at the margins of the terrain are the folds the axes of which are parallel to the strike of the Terskey and Ili oceanic sutures. The Late Paleozoic folds have roughly similar trend. With the absence of a stratigraphic contact between the Early Paleozoic rocks and the Devonian or Carboniferous deposits, it is difficult to distinguish between the results of Early Paleozoic and Late Paleozoic folding. A different situation exists in the internal parts of the terrain, where as a result of tension interference the Early Paleozoic folds have different directions and strike at an angle to the trend of the later folds (Figure 7).

\subsection{Ili Oceanic Basin}

[109] The northern Tien Shan spurs, namely, the Chu-Ili mountains include Early Paleozoic ophiolites. Their serpentinite melange, harzburgite, dunite, gabbro, basalt, picrite, amphibolite, and red chert have tectonic relations with one another, and often with the surrounding rocks. The ophiolite association includes also cherts and siliceous shales with limestone interbeds containing brachiopods, conodonts, and graptolites of Middle-Late Cambrian, Early Ordovician, and Llanvirnian ages. This zone also includes eclogites, possibly forced out of the subduction zone. All of these rocks compose folded tectonic nappes. The $\mathrm{Pb}-\mathrm{Pb}$ age of 510 million years was found for the plagiogranites from the ophio- 


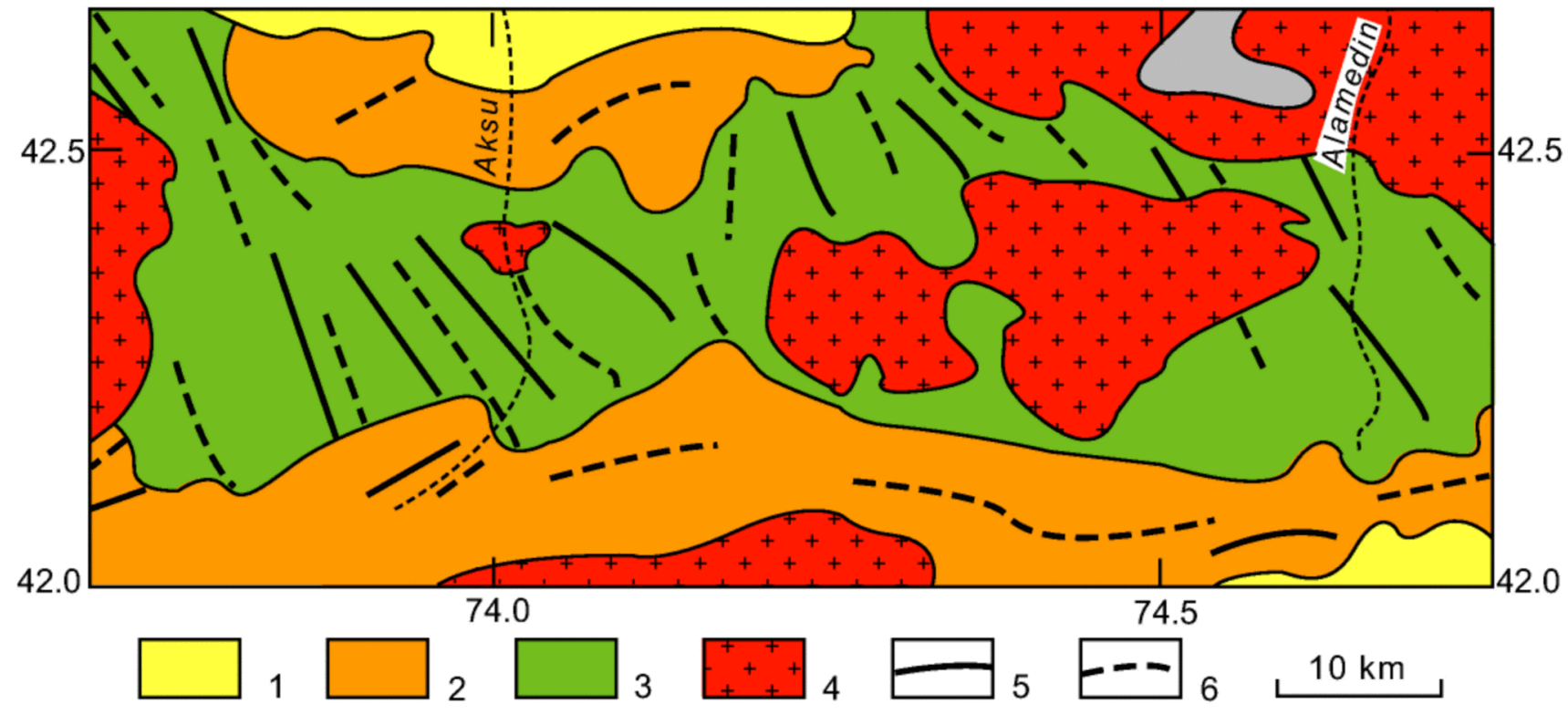

Figure 7. The folds of the Ordovician and Middle Paleozoic rocks in the central segment of the Kirghiz Ridge, after the data reported by I. P. Zakharov, K. D. Pomazkov, and the author of this paper: (1) Cenozoic, (2) Devonian and Lower Carboniferous, (3) Middle and Upper Ordovician, (4) granites, (5) anticlines, (6) synclines.

lite zone [Gruschka et al., 1998]. The deposits with Middle Ordovician fauna contain pebbles of ultrabasic rocks, gabbro, and basalt. The ophiolites are overlain unconformably by Late Ordovician terrigenous rocks.

[110] The overthrust remnants, composed of the ophiolites of this zone, occur in the Kendyktas, Kungey and Transili ridges. Serpentinized dunite, harzburgite, lherzolite, and wehrlite (300 $\mathrm{m}$ thick) were found at the base of one of the outliers (Sarytau klippen) in the Transili Ridge. Following upward are cumulative gabbro and pyroxenite $(800 \mathrm{~m})$, gabbro diabase $(500 \mathrm{~m})$, a layer of parallel dikes $(500 \mathrm{~m})$, and pillow basalt (1000 m) [Avdeev and Kovalev, 1989; Ges, 2002].

[111] The western segment of the North Ketmen Ridge includes several lenticular tectonic blocks composed of ophiolite and restricted by Late Paleozoic faults. One of the blocks includes a tectonic slab composed of ophiolite, which overlies the sequence of sandstones, conglomerates, and limestones with Llandeilian trilobites and Middle Ordovician brachiopods. The pebbles of the conglomerates represent many rocks of the ophiolite association. The section across the ophiolite slab begins with serpentinized harzburgite including blocks of rodingite and listvenite. Following above are gabbro diabase and pillow basalts $(300 \mathrm{~m})$, and then phosphate-phthanite rhythmic beds with sponge spicules. Another tectonic block, more than $2 \mathrm{~km}$ wide, includes a tectonic melange composed of broken globular basalt, red chert, serpentinite, listvenite, gabbro, chlorite schists, and other rocks.

[112] The ophiolites, exposed in the Chu-Ili mountains and in the Transili and Kungey ridges, are the crust fragments of the Early Paleozoic Ili oceanic basin. The petrochemical and geochemical characteristics of the volcanic rocks from the ophiolite association correspond to MOR basalts [Ges, 2002]. This oceanic crust had been abducted over the Issyk Kul sialic block in Middle Ordovician time, which is proved by the tectonic overlapping of the ophiolites over the Llandeilo neritic rocks and by the finds of ophiolite fragments in the rocks of this age.

[113] The suture of the Ili oceanic basin is the northern boundary of the Early Paleozoic Issyk Kul Terrain (Figures 2 and 3).

\subsection{Borohoro Terrain}

[114] This terrain (Figure 2) occupies the territory of the Borohoro Ridge in the Eastern Tien Shan Region and of the Dzungar Ridge in Eastern Kazakhstan. This terrain has an ancient metamorphic basement, on which volcanic and sedimentary rocks accumulated during the Paleozoic.

[115] The oldest rocks are gneisses which were dated 1.52.0 billion years using the $\mathrm{Sm}-\mathrm{Nd}, \mathrm{R}-\mathrm{Sr}$, and $\mathrm{U}-\mathrm{Pb}$ methods [Filatova and He, 2002]. Following above are dolomites (with phosphorites), cherts, and limestones with Late Proterozoic microflora and stromatolites. These rocks are overlain unconformably by a sequence of limestones, siltstones, and phosphate-bearing schists with diamictite interbeds, common for the Sinian rock sequences. The diamictites are overlain by phosphate-bearing siltstones and cherts, which are overlain conformably by limestones with Late Cambrian trilobites and brachiopods. The Lower Ordovician rocks are represented by argillite, siltstone, sandstone, and olis- 
tostromes (?), the Middle Ordovician rocks being represented by sandstones, siltstones, and acid and intermediate volcanics. These rocks are cut by Early Paleozoic granites [Gao et al., 1998; Hsu et al., 1994].

\section{South-Turkestan Domain}

[116] The rocks of this domain composed the large AlayTarim Paleozoic continent. At the present time they compose the Tarim Massif of ancient rocks, the Paleozoic cover of this massif, and the South Tien Shan geological province. Discussed in this paper is the structure of the Tien Shan part of the South Turkestan Domain.

\subsection{Western Tien Shan}

[117] Basement. In the Western Tien Shan the basis of the Alay-Tarim continent is exposed in the Baysun, Suluterek, Garm, and Gorif massives of metamorphic rocks.

[118] The rocks of the Baysun Massif are widespread in the mountains of the same name, namely, in the southern spurs of the Gissar Ridge. They are represented by a thick gneiss and crystalline schist complex. The age of zircons from these rocks was estimated by an alpha-lead method to be $660-700$ and 1120-1280 million years, and that of the pyroxene, to be 1750 million years [Mitrofanov, 1982].

[119] The Suluterek Massif resides at the southern end of the Fergana Ridge. It is composed of gneiss and crystalline schist which are overlain unconformably by sericite-chlorite and sericite-quartz phyllites, marbles, and quartzites. The age of these rocks is unknown; they are overlain by Late Paleozoic deposits. It is possible that in the Suluterek Massif the basement of the Tarim platform was brought to the ground surface.

[120] The Garm Massif resides in the Karategin Ridge. It includes the old and Paleozoic rocks, which are in tectonic relations. The ancient block is composed of gneiss, migmatite, amphibolite, quartzite, marble, and crystalline schist (Karategin, Sangikar, Garm, and other formations, 5000-8000 m thick). The significant amount of them are metamorphic ultrabasic and basic rocks. These rocks experienced granulite-facies metamorphism and amphibolitefacies retrograde metamorphism. The $\mathrm{Pb}-\mathrm{Pb}$ ages of the biotite gneiss and migmatite were found to be 2.6-3.0 billion years, and those of the diaphthorites, to be $600 \pm 150$ million years. The Paleozoic rocks are thrust over these ancient rocks [Melnichuk, 1987].

[121] The Gorif Massif is composed of metamorphic rocks which are exposed in the eastern segments of the Zeravshan and Gissar ridges. This massif consists of tectonic slabs, composed of metamorphosed basic rocks, jasper quartzite, graywacke, and pelite, and includes lenses of serpentinized harzburgite and metagabbro. In terms of their petrochemical characteristics these metabasic rocks correspond to oceanic tholeite basalts [Duk, 1995]. These rocks are transformed to schists with chlorite, actinolite, winchite, and crossite. The metamorphism of these rocks developed in the temperature range of $450-500^{\circ}$ with the pressure amounting to 5-8 kbar. The $\mathrm{Pb}-\mathrm{Pb}$ age of the zircons from the metabasic rocks, determined using the method of thermionic emission, was found to be $1050 \pm 160$ million years. Paleozoic rocks are thrust tectonically over the Gorif Massif [Duk, 1995; Melnichuk, 1989].

[122] The rocks of the Gorif Massif seem to represent the rock complex of the South Tien Shan metamorphic core. The tectonic contact of the ancient rocks of the massif with the Paleozoic rocks, marked by mylonites, is the surface of tectonic detachment in the roof of the metamorphic core. The ancient rocks of the Garm Massif can be of the same origin. The Gorif and Garm rock complexes are similar to the metamorphic core of the North American Cordilleras [Coney, 1980], yet, contrary to the core of the latter, the rocks discussed reside in the passive margin of the Paleozoic continent. The exposure of the metamorphic core was caused by the extension of the crust and coincided with the culmination of the magmatism. The most probable time of the South Tien Shan metamorphic core rising was the Permian time, when extension zones originated under the shearing conditions and numerous intrusions developed [Bazhenov et al., 1999]. The rocks of the metamorphic core can be localized by the formation of an extension zone by the operation of a pull-apart system.

[123] Vendian and Cambrian. The Vendian and Lower Paleozoic rocks are known in secondary occurrences, in the form of blocks in melange, olistoliths in some younger olistostrome, tectonic lenses, and overthrust klippens. The thicknesses of such fragmental sections is usually not higher than $100 \mathrm{~m}$.

[124] Limestones with Vendian microphytoliths were discovered in the Alay Ridge and its piedmont. Cambrian rocks were described in many areas of the Turkestan, Alay, and East Alay ridges. These are shallow-sea deposits, such as limestones, calcareous siltstones, sandstones, and occasional chert interbeds containing Early Cambrian archaeocyathids and also Middle and Late Cambrian trilobites and brachiopods. It can thus be concluded that during the Cambrian time carbonate rocks, common for passive margins and intracontinental seas, accumulated during the Cambrian time in the significant parts of the region discussed. It is possible that Vendian limestones accumulated under the similar conditions.

[125] A large tectonic block of the Alay Ridge includes the basalts containing interlayers of phthanite, sandstone, and limestone with archaeocyathids and brachiopods of the Early Cambrian Toyonian time. Another outcrop includes a breccia with basalt fragments alternates with limestones containing Early Cambrian (Tommotian) archaeocyathids [Bakirov and Burtman, 1984].

[126] Ordovician. The rocks of this age are found in carbonate, terrigenous, and siliceous facies and in the form of oceanic crust fragments.

[127] Carbonate rocks. Found at the northern slope of the Alay Ridge and in its piedmont area were limestones with Arenigian brachiopods, Arenigian-Llanvirnian conodonts, and Late Ordovician trilobites in their secondary positions. 
Similar positions are occupied by carbonate rock blocks with Middle-Late Ordovician fauna at the northern slope of the Zeravshan Ridge.

[128] Terrigenous and siliceous deposits. Found at the southern slope of the Alay Ridge in the terrigenous melange of Permian age, were blocks of carbonaceousargillaceous, aleuritic, argillaceous-silicic, and silicic shales with Arenigian, Llanvirnian, and Llandeilo-Caradocian graptolites. The thickness of these rocks in the blocks is higher than $200 \mathrm{~m}$.

[129] Exposed in the northern piedmont areas of the Turkestan Ridge are siltstones and argillites with Tremadocian graptolites. Aleuritic, argillaceous, and siliceous shales with Middle Ordovician conodonts and graptolites are known in the western segment of the Turkestan Ridge. Outcropping at the western end of the Malgusar Mountains is an isoclinally folded and boudinaged distal flysch with Early and Middle Ordovician conodonts. Known in the Zeravshan, Turkestan, and Alay ridges are fragments of stratigraphic sequences of composed of shale with Middle Ordovician trilobites and brachiopods, and also of sandstones and siltstones with Late Ordovician graptolites.

[130] The Late Ordovician rock sequence containing tuffaceous rocks is exposed in the western segment of the Zeravshan Ridge (Shakhriomon Formation, $400 \mathrm{~m}$ thick). Its power part is composed of siltstones and quartz and polymictic sandstones with limestone lenses where Late Llandeilian-Early Caradocian brachiopods, trilobites, and cystoideas were collected. The middle part of this rock sequence is composed of conglomerates, tuffaceous sandstones, and acid tuff, devoid of any organic remains. The upper part of this rock sequence is composed of sandstones, siltstones, and limestones with Ashgillian brachiopods, corals, and trilobites.

[131] At the southern slope of the Gissar Ridge the Middle and Late Ordovician rocks are represented by argillite, quartz sandstone, and sandy limestone with brachiopods and corals (Chosh Formation). Also occurring in this area are metamorphic greenschists, phyllites, quartz sandstones, and marble (Obizarang Formation), in which Cambrian and Early Ordovician microfossils and chitinozoans were identified.

[132] Although the primary relationships between the fragments of the rock sequences discussed are unknown, it can be concluded that in the West Tien Shan shallow-sea carbonate rock were deposited in the territory of the South Turkestan domain during the Ordovician on the shelf, and deep-sea siliceous and terrigenous rocks, including turbidites, were deposited on the continental slope.

[133] The rocks of the oceanic crust. The northern slope of the Alay Ridge includes an allochthonous slab resting in the trough of a synform fold (Sarytal ophiolites). The lower part of this allochthon $(500 \mathrm{~m})$ is composed of dunite, harzburgite, pyroxenite, cumulative gabbro-norite, and ophicalcite breccias. The $\mathrm{Pb}-\mathrm{Pb}$ age of zircons from the pyroxenite, found by the method of thermoionic emission, was $1330 \pm 12$ million years [Komarevtsev et al., 1987]. Following above are volcanic sediments. The rock sequence begins with hematite cherts with Early Ordovician conodonts $(25 \mathrm{~m})$. These rocks include conglomerate lenses with gabbroid pebbles. The contact between these rocks and the underlying ophicalcite breccia is complicated by a differentiated sill of ultrabasic and basic rocks, yet, is preserved, in places, under the sill. The chert is overlain by spherolitic olivine basalts and picrite $(150 \mathrm{~m})$ with Early and Middle Ordovician radiolarians and conodonts in chert interbeds. Following above are tholeite pillow basalts $(500 \mathrm{~m})$ including hyaloclastite, sandstone, and chert interlayers. Above follow tholeitic pillow basalts (500 $\mathrm{m}$ thick), including the interlayers of hyaloclastite, sandstone, and chert with Llandoverian graptolites and Late Silurian-Early Devonian radiolarians [Burtman et al., 1977; Kurenkov et al., 2002].

\subsection{Central Tien Shan}

[134] The lower part of the visible Sinian rock sequence in the Kelpintag Ridge is composed of red continental gravelite, sandstone, and shale. Above follows a 600-meter thick sequence of basalt and rhyolite tuff and diamictite. The tuff varies from alkaline basalt to trachyandesite, its geochemical characteristics suggesting the accumulation of the rocks in a continental rift [Chen et al., 1999]. The upper part of the Sinian rock sequence consists of carbonate rocks with stromatolites, the lower part of the Cambrian rock sequence is composed of phosphate-bearing silicite and shale. Following above are shallow-sea carbonate rocks with trilobites. Accumulated in the Ordovician were micrite and bioclastic limestone containing trilobites [Chen et al., 1999; Liu et al., 1997]. Early Paleozoic limestones and shales are also known in the Kokshaal Ridge.

[135] The character of the Sinian and Early Paleozoic sedimentary rocks agrees with their sedimentation at the passive margin of the continent.

\subsection{Eastern Tien Shan}

[136] Basement. The basement of the Alay-Tarim Paleozoic continent in the Eastern Tien Shan is raised to the ground surface at the edge of the Tarim Basin. Outcropping near the Aksu Mountain are metamorphic schists with crossite and glaucophane, developed after the basic lavas and pelite, and metamorphic sandstones of arcose-quartz composition. The Rb-Sr age of the metamorphism of these rocks was found to be 1700-1900 and 1100 million years. Exposed at the southern slope of the Haerke Ridge are gneisses and crystalline schists, with granites, gneisses, schists, migmatites, and marbles outcropping in the Kuruktag Ridge. The Archean and Lower Proterozoic rocks of this ridge have $\mathrm{Sm}-\mathrm{Nd}$ isochronous ages of their protoliths ranging from 2200 to 3300 million years, the U-Pb ages of their zircons ranging from 2100 to 2600 million years [Hu et al., 2000].

[137] The Riphean rocks are represented by metamorphosed clastic and carbonate rocks with stromatolites. These rocks are cut by granites whose R-Sr age was found to be $920 \pm 90$ million years. Some of the rock sequences include layers of metamorphic intermediate and acid volcanic rocks which had accumulated during 1 billion years [Filatova and $\mathrm{He}, 2002]$. 
[138] Sinian and Early Paleozoic. The Sinian rocks containing microflora rest unconformably on the older rocks. In the Northrn Kuruktag Ridge these are sandstones and siltstones with interbeds of conglomerates, limestones, and acid volcanics, diamictites residing at the Vendian level. The Lower Cambrian rocks are represented in the North Kuruktag Ridge by radiolarites, phosphates, and carbonates with archaeocytes, brachiopods, and trilobites. The Lower Cambrian rocks include basalt, andesite, and tuff layers. The Middle and Late Cambrian and Ordovician rocks are represented by shallow-sea marine carbonate rocks (micritic and algal limestones, calcarenites, and dolomites) with trilobites, brachiopods, pelecypods, and corals.

[139] Ranked as Sinian in the South Kuruktag Ridge is a thick sequence of volcanic and volcaniclastic rocks of basic and intermediate composition at the base, and of intermediate and acid composition at the top, which alternate with terrigenous clastic rocks. These rocks seem to have accumulated in a continental rift. The Vendian and Lower Cambrian rock sequences are represented in this area by carbonate-terrigenous rocks with diamictites in the Vendian rocks and by basalts in the Lower Cambrian. The Middle and Upper Cambrian intervals are composed of shallow-sea carbonate rocks, those of the Ordovician and Lower Silurian interval being represented by a thick $(5 \mathrm{~km})$ deep-sea flysch sequence of sandstones, siltstones, argillite, and radiolarite with conodonts and graptolites. The flysch rocks include interlayers of acid and intermediate lava interlayers. Some researchers believe that all of these rock sequences accumulated in an aulacogen which had been formed in Sinian time at the Tarim Platform [Chen et al., 1999; Hsu et al., 1994; Liu et al., 1997].

[140] In the area of the Aksu town the ancient basement is overlain unconformably by unmetamorphozed terrigenous deposits with diamictites, $3000 \mathrm{~m}$ thick, whose U-Pb ages were found to be 774 and 740 million years. The Lower and Middle Cambrian rocks are represented by limestones $(350 \mathrm{~m})$, and the Upper Cambrian and Ordovician rocks, by limestones, siltstones, and sandstones $(1000 \mathrm{~m})$. At the basis of the Lower Cambrian rocks, the carbonate rocks include pelagic cherts, the deposition of which is also believed to be associated with continental rifting [Brezhnev, 1994; Mazarovich et al., 1995; Yu et al., 2005].

[141] The Haerke Ridge is known to include metamorphic rocks, having the Rb-Sr age of 645-676 million years, and carbonate rocks containing Early Paleozoic trilobites [ Wang et al., 1994].

\section{Tectonic Evolution and Geodynamics}

[142] Models of the Early Paleozoic tectonic evolution of the Tien Shan region and its constituents were offered by many researchers [Bakirov and Maksumova, 2001; Burtman, 1997; Kheraskova, 1998; Lomize et al., 1997; Maksumova et al., 2001; Mikolaichuk et al., 1997; Zamaletdinov and Osmonbetov, 1988]. All of these models have a common theoretic basis and show a significant similarity. The geodynamic model presented in Figure 8 illustrates the main features of the Early Paleozoic evolution of tectonic activity in the Tien Shan region.

[143] During the Riphean the territory of the Tian Shan tectonic zones belonged to the continent, known in the literature as East Gondwana, Rodinia, or Indo-Australia. Carbonate and carbonate-terrigenous rocks were deposited in the shallow sea over the larger area of the Tarim Massif, while carbonate sediments, quartz sands, and clays accumulated in the intracontinental seas in the territory of the North Turkestan Domain. Volcanic deposits of acid and bimodal composition accumulated in continental rifts. Intensive volcanism has been dated 830-850 million years [Bakirov and Maksumova, 2001; Kiselev, 1999]. It is possible that this volcanic activity was caused by the rise of a mantle diapir, which preceded the break-up of the continental crust and oceanic spreading.

[144] During the Sinian, the continental rifting processes continued as proved by rift-origin deposits of this age developed in the Nalaqin, Naryn, Chatkal, and Talas tectonic zones, and in the Kuruktag Range of the South Tien Shan. The continental rifting activity was completed by the opening of the Tien Shan paleooceanic basins, such as the Turkestan, Terskey, and Ili basins, as well as of the Kun Lun oceanic basin, which separated the Alay-Tarim sialic block from East Gondwana [Burtman and Samygin, 2001].

\subsection{Turkestan Oceanic Basin and Its Margins}

[145] During the Early Paleozoic this oceanic basin separated the Alay-Tarin continent from the microcontinents of the North Turkestan Domain of Tien Shan, namely, from the Syr Darya microcontinent during the Cambrian and EarlyMiddle Ordovician, and from the Kirghizian microcontinent during the Late Ordovician. The West Tien Shan region is known to include the Early Paleozoic and pre-Paleozoic (?) rocks of the Turkestan oceanic crust. These are the pyroxenites and metabasic rocks with the Riphean $\mathrm{Pb}-\mathrm{Pb}$ age of zircons in the Alay Ridge, the ultrabasic rocks with the Early Cambrian $\mathrm{Pb}-\mathrm{Pb}$ age of the zircons in the North Fergana Area, and the Early Paleozoic oceanic basalts in the Alay Ridge. During the Ordovician these basalts experienced metamorphism in the accretion prism at the active margin of the oceanic basin.

[146] The data obtained during the study of the oceanic rocks in the Alay Ridge suggest that a marginal sea and an oceanic island arc existed in the Turkestan oceanic basin in Ordovician time. The rocks of the Ordovician oceanic arc are preserved also in the Chatkal Ridge. Known in the Nalaqin zone are Lower Paleozoic volcanic rocks which might have accumulated at the Turkestan margin of the Syr Darya Terrain or in the island arc in the Turkestan oceanic basin.

[147] Widespread in the Western Tien Shan are the Cambrian and Ordovician rocks of the carbonate shelf and the Ordovician silicites and turbidites of the continental shelf of the Alay-Tarim Terrain. Thick deep-sea flysch deposits accumulated in the Kuruktag rift in Ordovician and Early Silurian time. Accumulating west and north of the rift were shallow-sea, mainly carbonate deposits, common for the passive oceanic margin. 

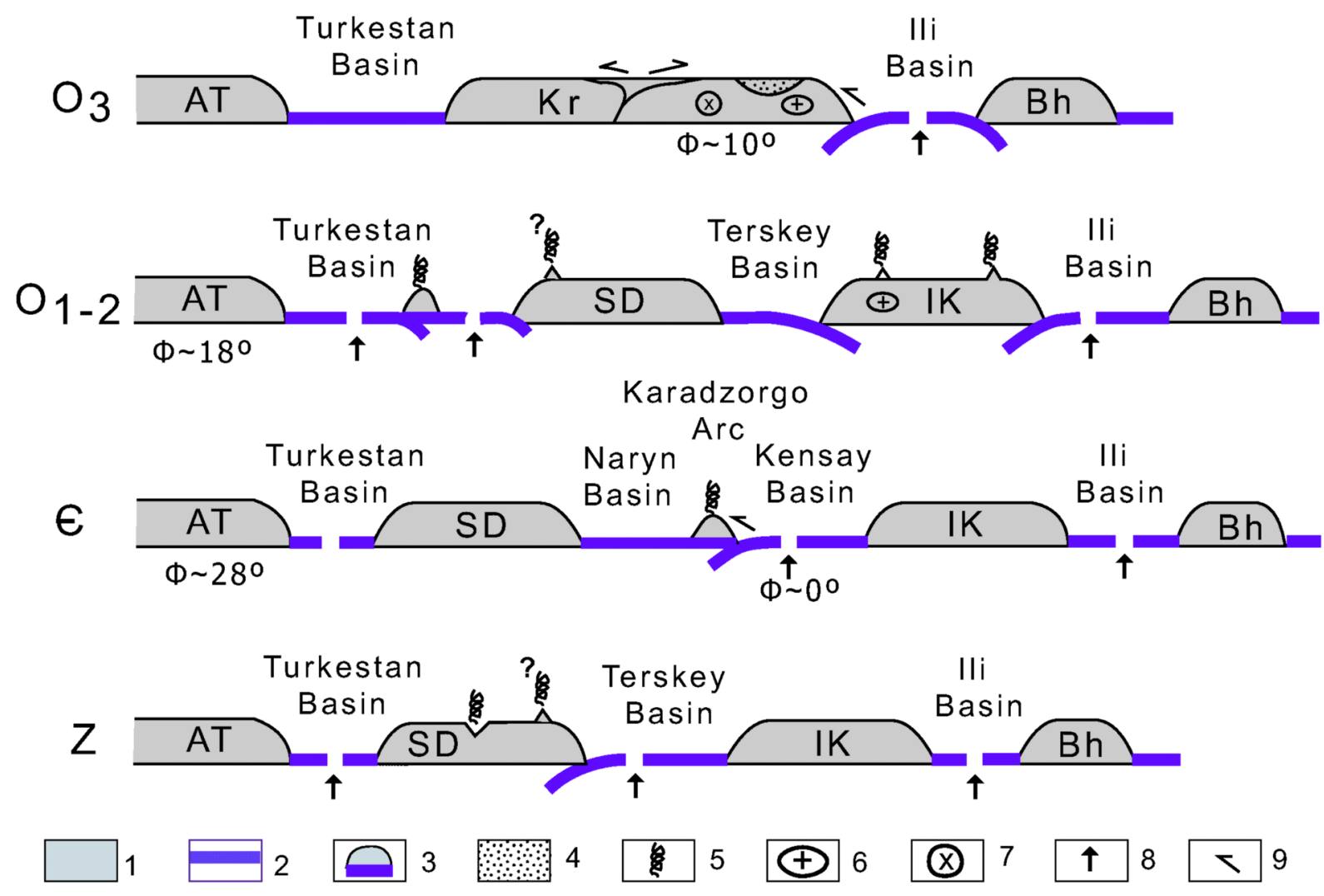

Figure 8. A geodynamic model for the Tien Shan tectonic evolution. AT denotes the Alay-Tarim continent; Bh denotes the Borohoro microcontinent: IK, the Issyk Kul microcontinent; Kr, the Kirghiz microcontinent: SD, the Syr Darya microcontinent; $\Phi$, the paleomagnetic paleolatitudes. (1) continental crust, (2) oceanic crust, (3) oceanic island arcs, (4) volcanism, (5) subduction granitoids, (6) collision granitoids, (7) oceanic spreading zones, (8) ocean spreading zones, (9) obduction and overthrusting trends.

[148] Different views were offered in the literature concerning the size of the Tien Shan paleooceanic basins and of the positions of the sialic blocks in them [Burtman, 1999; Didenko et al., 1994; Fedorenko and Miletenko, 2002; Kurenkov et al., 2002; Mossakovsky et al., 1994; Sengör and Natalin, 1996; Sengör et al., 1993; Zonenshain et al., 1990; to name but a few]. The data available for the Cambrian biogeography and the results of studying the paleomagnetism of the rocks allow one to estimate the size of the Turkestan oceanic basin.

[149] Biogeographical data. The biogeographical studies were carried out using archaeocyathids, brachiopods, and trilobites. The Cambrian archaeocyathids and brachiopods, which had migrated from one center do not help to solve the tectonic problem discussed [Burtman, 1999]. The high differences of the trilobite fauna in the Early Cambrian biogeographic provinces [Repina, 1985a, 1985b] make trilobites an attractive group for paleotectonic reconstructions.

[150] Trilobites are scarce in the Tommotian rocks. The Atdabanian time clearly shows two biogeographic regions, namely, the Indian-Australian and Pacific-Atlantic ones. The Indian-Australian biogeographic region existed to the end of the Early Cambrian. Its characteristic fossils are the trilobites of the Redlichiidae Family, which were found in the Early Cambrian rocks of Australia, India, Iran, and at the Tarim, China, and Korea platforms.

[151] The Pacific-Atlantic biogeographic region embraced the territory of modern Asia, located north of the Tarim and China platforms (North Asia), as well as Europe, North Africa, and North America. This region includes several biogeographic provinces, the relationships among which changed from century to century. In terms of this study of great interest is the situation in North Asia. In the Atdabanian century, characteristic of this territory were the trilobites of the Olenellina suborder, in Botomian and Toyonian times - Protolenidae Family. This biogeographic region includes the Altay-Sayan Province embracing the Ural, Kazakhstan, and Mongolia-Okhotsk regions. These territories are distinguished by a common trilobite fauna, similar to that of the Siberian Platform.

[152] The results of studying trilobites in the Talas tectonic zone of the North Tien Shan [Mambetov and Repina, 1979] suggest that during the Tommotian and Atdabanian centuries the basins of the Syr Darya Terrain and Siberian Platform were communicating with one another, whereas in 
the Botomian and Toyonian time they were isolated from one another. In the Syr Darya Terrain, the rocks of the Toyonian Stage include Redlichia chinensis Walcott remains, characteristic of the rock sequences of China, Korea, India, and Australia, which suggests that this basin was connected with the Indian-Australian biogeographic province during Toyonian time.

[153] The difference between the Indian-Australian and Pacific-Atlantic biogeographic regions is usually explained by the existence of a Cambrian Ocean between them, which precluded the migration of benthonic fauna. At the present time the boundary between these biogeographic regions is traced along the northern edge of the Alay-Tarim Paleozoic continent (that is, along the suture of the Turkestan Ocean) and the China Platform.

[154] To sum up, the biogeographic information available suggests the significant size of the Turkestan oceanic basin in Early Cambrian time, sufficient to serve as a barrier between different trilobite communities. At the end of the Early Cambrian (in Toyonian time) the effect of this barrier diminished, apparently as a consequence of the narrowing of the Turkestan Ocean space.

[155] Paleomagnetic data. The paleomagnetic results were obtained during the study of the Cambrian rocks in the North-Turkestan and South-Turkestan domains separated by the Turkestan oceanic basin. These data suggest that the Late Cambrian oceanic basins of the Karakatty Ridge, which were emplaced in the Kensay forearc basin, had flowed in the vicinity of the equator at the latitude of $0 \pm 4^{\circ}$ [Dvorova and Kurenkov, 2004]. At the northern margin of the Tarim Platform, during the study of the paleomagnetism of Late Cambrian limestones in the Kuruktag Ridge, their paleolatitude was found to be $28^{\circ}$ [Zhao et al., 1997]. These data suggested that the total width of the Terskey and Turkestan oceanic basins had been $2500 \mathrm{~km}$ or larger in the direction of the paleomeridian in Late Cambrian time.

[156] The paleomagnetic study of the Ordovician rocks in the Alay-Tarim continent and in the Kirghiz microcontinent showed that in Ordovician time the long axes of these terrains had strikes close to the meridional one [Burtman et al., 2003; Chen et al., 1999]. This does not allow one to estimate the widths of the oceanic basins which separated the microcontinents in Ordovician time from paleomagnetic data.

\subsection{Ili Oceanic Basin and Its Margins}

[157] The Ili Basin separated the Borohoro and Issyk Kul microcontinents. Judging by the age of the ophiolites, the oceanic basin existed as early as the Early Cambrian. Apparently, it originated in Vendian time. The Borohoro Terrain was a microcontinent, the Ilian margin of which was passive up to the Middle Ordovician, when it became an active one.

[158] The subduction of the oceanic crust under the Ili edge of the Issyk Kul microcontinent began in Tremadocian time. This resulted in the formation of a marginal belt of subduction volcanics and granites. During the Early-Middle Ordovician the Issyk Kul microcontinent existed as a conti- nental volcanic island arc with magmatic belts at two margins. Volcanic activity continued in both belts up to the Caradocian time.

[159] The Middle Ordovician time witnessed the obduction of the oceanic crust of the Ili oceanic basin over the northern edge of the Issyk Kul Terrain. The obduction of the ophiolites might have accompanied the formation of the accretion prism, or might have been a result of the collision and the closure of the oceanic basin. Widespread at the Ili margin of the Issyk Kul are the Late Ordovician-Silurian collision granites and the Early Silurian subduction-type calc-alkalic volcanic rocks. They suggest the accretion origin of the Middle Ordovician overthrust sheets and the later (Silurian) closure of the Ili oceanic basin.

\subsection{Terskey Oceanic Basin and Its Margins}

[160] This basin divided the Syr Darya and Issyk Kul microcontinents. There are data proving the existence of the Terskey oceanic basin in Early Sinian time. Its margin experienced accretion, associated with the latter was the formation of the pre-Vendian overthrusts of the Karadzorgo Ridge. During the Vendian the fragments of the rocks of the oceanic crust in the Minor Karatau Ridge got into the sediments which accumulated on the continental crust. Consequently, by this time part of the oceanic crust had been deformed (apparently in the accretion prism) and experienced abrasion and erosion.

[161] In the Early Paleozoic, the Syr Darya edge of the Terskey oceanic basin was passive, the Issyk Kul edge being an active one (Figure 8). During the Cambrian to the beginning of the Ordovician, the Karadzorgo oceanic island arc divided the Terskey Basin into the Naryn back-arc basin and the Kensay fore-arc basin. The oceanic crust of the Kensay Basin was subducted under the Karadzorgo volcanic arc and abducted under the same arc. Formed at the front of the arc was an accretionary prism which is overlain, with an angular unconformity, by Late Arenigian-Llanvirnian marine sediments.

[162] During the Arenigian the Kensay Basin was closed and the Karadzorgo Arc connected with the Issyk Kul microcontinent (collision 1). Widespread in the territory of the Dzumgal Ridge are Ordovician turbidites and graywackes, composed of the rock fragments of the island arc, and of continental arcose rocks. These turbidites seem to date the beginning of the Karadzorgo island arc collision with the microcontinent. Unfortunately, the faunal remains, found in the turbidites, cannot date these rocks with the expected accuracy. More definite data were obtained in the Karakatty Ridge containing the volcanic rocks of the Karadzorgo island arc, containing Middle Arenigian conodonts. The upper part of this rock sequence includes abundant continental rock material as a consequence of the collision of the island arc with the microcontinent.

[163] As a result of the Arenigian collision-1, the rocks of the former Karadzorgo arc formed an accretion prism at the edge of the Issyk Kul microcontinent, on which turbidites began to accumulate. Collision-1 was followed by the subduction of the oceanic crust of the Naryn Basin under the 
Issyk Kul microcontinent. As a result of this, an igneous rock belt originated in the Middle Ordovician at the Terskey edge of this microcontinent.

[164] During the Middle to the beginning of the Late Ordovician, the subduction of the oceanic crust of the Naryn Basin under the Issyk Kul microcontinent resulted in the collision of the Issyk Kul and the Syr Darya terrains (collision2 ) and in their amalgamation into the Kirghiz microcontinent (Figure 8).

[165] One of the consequences of the collision- 2 was the cessation of turbidite accumulation at the southern margin of the Issyk Kul Terrain at the end of the Middle Ordovician. At the end of the Middle to the beginning of the Late Ordovician, thrust over the Issyk Kul Terrain were the crustal rocks of the Terskey oceanic basin, the rocks of the accretion prism (composed of the rocks of the Karadzorgo island arc and of the Kansay Basin), and the rocks of the continental slope of the Issyk Kul Terrain. Apparently existing were overthrust sheets, composed of the rocks of the Syr Darya Terrain. This is proved by the Late CambrianTremadocian limestone olistolits in the Middle Ordovician turbidites, widespread in the Son Kul Lake area. It is highly probable that these limestones are the fragments of the overthrust sheet composed of the rocks of the Syr Darya Terrain [Ges, 1980]. The Burenkhey overthrust sheets, resting now on the Issyk Kul Terrain, seem to be also composed of the rocks from Syr Darya Terrain.

[166] The remnants of the nappe are scattered over a belt located in the area of the Kirghiz, Susamyr, Dzumgal, Terskey, and other ridges (Figure 3). The width of this belt and, accordingly, the magnitude of the overthrust faults is larger than $60 \mathrm{~km}$.

[167] Associated with collision-2 was also the formation of nappes in the Syr Darya microcontinent. They are composed of the rocks of the continental slope and shelf and are widespread in the Talas tectonic zone. The rocks of the Uzunahmat unit seem to have accumulated in an accretion prism at the edge of the Issyk Kul Terrain, where they experienced dynamic metamorphism. Later, during the collision of the Syr Darya and Issyk Kul terrains, they were thrust over the edge of the Syr Darya Terrain. In the course of the collision the Talas unit subducted under the Kumyshtag unit, and then both of them were overlain by the Uzunahmat nappe. The further development of the collision process resulted in the simultaneous folding of all structural units of the Talas region. The axes of the resulting folds are parallel to the suture of the Terskey oceanic basin.

[168] During the Middle and Late Ordovician an orogenic molasse was formed in the newly formed Kirghiz microcontinent. It was subjected to paleomagnetic study. Identified in the Llanvirnean rocks exposed in the central segment of the Kirghiz Ridge was a paleomagnetic component of Middle or Late Ordovician age. It had originated at the latitude of $10 \pm 2^{\circ}$ [Burtman et al., 2003]. The paleomagnetism of the Late Ordovician molasse was studied at the northern slope of the Moldo Ridge, in the Susamyr Ridge, and at the western termination of the Kirghiz Ridge. The results of this study provided the following paleolatitude determinations: $11 \pm 2^{\circ}, 9 \pm 3^{\circ}$, and $6 \pm 5^{\circ}$ [Bazhenov et al., 2001, 2003]. It appears that the Tien Shan microcontinents and the Alay-
Tarim continent resided in the southern hemisphere during the Early Paleozoic time.

[169] Acknowledgment. This paper was based on the results of the study supported by the Russian Foundation for Basic Research, Project no. 04-05-64899.

\section{References}

Akhmedov, N. A., (Ed.) (2000), The Stratified and Intrusive Rocks of Uzbekistan (in Russian), 541 pp., Institute of Mineral Resources, Tashkent.

Alekseev, D. V. (1997), Folded nappes in the Minor Karatau, Dokl. Ros. Akad. Nauk (in Russian), 353, 220.

Avdeev, A. V., and A. A. Kovalev (1989), Ophiolites and Evolution of the Southwestern Segment of the Ural-Mongolian Foldbelt (in Russian), 229 pp., State University, Moscow.

Bakirov, A. B., and V. S. Burtman, (Eds.), (1984), Tectonics of the Tien Shan Variscides, Guidebook for the 27th Intern. Geol. Congress Excursion 032 (Kirghiz Republic), p. 74, Ilim, Frunze.

Bakirov, A. B., and R. A. Maksumova (2001), Geodynamic evolution of the Tien Shan lithosphere, Geol. Geofiz. (in Russian), 42, 1435.

Bakirov, A. B., M. Tagiri, K. S. Sakiev, and E. A. Ivleva (2003), The Early Precambrian rocks in the Tien Shan and their geotectonic setting, Geotectonics, 37, 368.

Baratov, R. D., (Ed.) (1976), Dismembering of the Stratified and Intrusive Rocks in Tadjikistan, 270 pp., Donish, Dushanbe.

Bazhenov, M. L., V. S. Burtman, and A. V. Dvorova (1999), The Permian paleomagnetism of the Tien Shan fold belt, Central Asia: Post-collision rotations and deformation, Tectonophysics, 312, 303, doi:10.1016/S0040-1951(99)00181-X.

Bazhenov, M. L., V. S. Burtman, N. M. Levashova, and A. V. Mikolaichuk (2001), The position of the KazakhstanKirghizian continent in Late Ordovician time from paleomagnetic data, Dokl. Ros. Akad. Nauk, 380, 82.

Bazhenov, M., A. Collins, K. Degtyarev, N. Levashova, A. Mikolaichuk, V. Pavlov, and R. Voo (2003), Paleozoic northward drift of the North Tien Shan (Central Asia) as related by Ordovician and Carboniferous paleomagnetism, Tectonophysics, 366, 113, doi:10.1016/S0040-1951(03)00075-1.

Bekzhanov, G., V. Koshkin, I. Nikitchenko, L. Skrinnik, T. Azizov, and A. Timush (2000), The Geological Structure of Kazakhstan, 395 pp., Acad. Mineral Resources, Almaty.

Brezhnev, V. D. (1994), The age and structure of the Tarim basement, Dokl. Ros. Akad. Nauk, 334, 607.

Burtman, V. S. (1997), Kyrgyz Republic, in Encyclopedia of European and Asian Regional Geology, edited by E. M. Moore and R. W. Fairbridge, p. 483, Hapman \& Hall et al., London.

Burtman, V. S. (1999), Some problems of the Paleozoic tectonic reconstructions in Central Asia, Geotectonics, 33(3), 262.

Burtman, V. S. (2006), Tien Shan and High Asia: Tectonics and Geodynamics in the Paleozoic, 216 pp., GEOS, Moscow.

Burtman, V. S., and S. G. Samygin (2001), Tectonic evolution of High Asia in the Paleozoic and Mesozoic, Geotectonics, 35(4), 276 .

Burtman, V. S., G. Z. Gurarii, and A. V. Dvorova (2003), The positions of the microcontinents in the Northern Tian Shan and Eastern Urals in the Ordovician and Silurian from paleomagnetic data, Geotectonics, 37(5), 352.

Burtman, V. S., V. L. Klishevich, L. N. Kotova, S. Kurenkov, B. B. Nazarov, and V. P. Chernyshuk (1977), New data for the Paleozoic ocean in South Fergana, Dokl. Akad. Nauk SSSR, 237, 668.

Chen, C., H. Lu, D. Jia, D. Cai, and S. Wu (1999), The closing history of the southern Tianshan oceanic basin, West 
China: Oblique collision orogeny, Tectonophysics, 302, 23, doi:10.1016/S0040-1951(98)00273-X.

Coney, P. J. (1980), Cordilleran metamorphic core complexes: an overview, in Cordilleran Metamorphic Core Complexes, Mem. Geol. Soc. Am., vol. 153, edited by P. J. Crittendon, P. J. Coney, and G. H. Davis, p. 7, Spec. Publ., London.

Dalimov, T. N., and T. Sh. Shayakubov, (Eds.), (1998), Uzbekistan Geology and Mineral Deposits (in Russian), 724 pp., University, Tashkent.

Demina, L. I., M. G. Lomize, and A. V. Avdonin (1995), The geodynamic characteristics of peridotites in the Sonkelie area, Herald of Moscow University, ser. geol. (in Russian), 1, 91.

Didenko, A., A. Mossakovskii, D. Pecherskii, S. Ruzhentsev, S. Samygin, and T. Kheraskova (1994), The geodynamics of Paleozoic oceans of Central Asia, Geol. Geofiz. (in Russian), 35(7-8), 59.

Dvorova, A. V., and S. A. Kurenkov (2004), The position and kinematics of the Early Paleozoic ophiolites in the North Tien Shan region from magnetic data, Dokl. Ros. Akad. Nauk (in Russian), 395, 82.

Duk, G. G. (1995),

Glaucophane Schists, Glaucophane Green Schists, and Ophiolite Complexes of the Ural-Mongolian Foldbelt (in Russian), 272 pp., Institute of Precambrian Geology and Geochronology, St. Petersburg.

Fedorenko, A., and A. Miletenko, (Eds.), (2002), Atlas of the Lithologic-Paleogeographic, Structural, Palinspastic and Geoenvironmental Maps of Central Eurasia, 200 pp., Sci. Research Inst. of Natural Resources, Almaty.

Filatova, L. I., and G. He (2002), Fragments of the Late Proterozoic Rhodinia Supercontinent in Xinjiang and in East Kazakhstan, Bulletin of the Moscow Society of Naturalists, Ser. Geol. (in Russian), 77(7), 3.

Gao, J., G. He, M. Li, X. Xiao, Y. Tang, J. Wang, and M. Zhao (1995), The mineralogy, petrology, metamorphic PTDT trajectory, and exhumation mechanism of blueschists, South Tianshan, Northwest China, Tectonophysics, 250, 151.

Gao, J., M. Li, X. Xiao, Y. Tang, and G. He (1998), Paleozoic tectonic evolution of the Tianshan Orogen, Northwest China, Tectonophysics, 287, 213.

Ges, M. D. (1980), Lower Paleozoic olistostromes in the Sonkul area, Dokl. Akad. Nauk SSSR (in Russian), 252, 931.

Ges, M. D. (1999), Magmatism and geodynamic evolution of the Tien Shan Caledonian Orogenic Belt, in Problems of Geology and Geography in Kyrghystan, edited by A. B. Bakirov and A. N. Dikikh (in Russian), p. 33, Ilim, Bishkek.

Ges, M. D. (2002), Ophiolites in the Tien Shan Caledonides: Their geodynamic types and tectonic position, in Geodynamics and Ecologic Problems in Mountainous Regions, Second International Symposium (in Russian), p. 46, Bild, Bishkek.

Gradstein, F. M., J. G. Ogg, A. G. Smith, W. Bleeker, and L. G. Lourens (2004), A new geologic time scale, with special reference to Precambrian and Neogene, Episodes, 27, 83.

Gruschka, S., A. Kroner, A. V. Avdeev, N. S. Seitov, and R. Oberhansli (1998), Early Palaeozoic Accretion of arcs and microcontinents in the Central Asian mobile belt of Southern Kazakhstan as deduced from $\mathrm{Pb}-\mathrm{Pb}$ zircon and $\mathrm{Sm}-\mathrm{Nd}$ ages, Terra Nova, 7, 340.

Hristov, S. E., and V. P. Chernyshuk (1987), Stratigraphy and structural elements of the Lower Paleozoic deposits of the Dzumgal Ridge, in Tien Shan Caledonides, edited by V. G. Korolev (in Russian), p. 79, Ilim, Frunze.

Hristov, E. V., and G. G. Shilov (1998), The deposits of the Ordovician epicontinental basin in the North Tien Shan area, Bulletin of the Moscow Society of Naturalists, Ser. Geol., $73(4), 39$.

Hsu, K. J., Y. Yao, J. Hao, P. Hsu, J. Li, and O. Wang (1994), The origin of the Chinese Tienshan by arc-arc collisions, Eclogae Geol. Helv., 87, 365.

$\mathrm{Hu}$, A., J. Borming, G. Zhang, Y. Chen, and Q. Zhang (2000), Crustal evolution and Phanerozoic crust growth in northern Xinjiang: $\mathrm{Nd}$ isotopic evidence: Part I, Isotopic characterization of basement rocks, Tectonophysics, 328, 15, doi:10.1016/S0040-1951(00)00176-1.
Jenchuraeva, R., A. Bakirov, M. Ghes, R. Seltmann, V. Shatov, and V. Popov, (Eds.), (2001), Mineral Deposits Map of Kyrgyzstan, Scale 1:1,000,000, 153 pp., FAO, London-Bishkek.

Kheraskova, T. N. (1998), Structural connections between Kazakhstan and Tien Shan from the end of the Riphean to the Early Cambrian, in The Geologic Problems of the UralMongolia Belt, edited by E. E. Milanovskiy and A. B. Veinmarn (in Russian), p. 27, State University, Moscow.

Kheraskova, T. N., S. V. Dubinina, A. R. Orlova, and E. A. Serezhnikova (1997), The Early Paleozoic North Tien Shan accretion-type rock complex, in Tectonic and Geodynamic Phenomena, edited by A. S. Perfiliev and Yu. N. Raznitsyn, p. 221, Nauka, Moscow.

Khudolei, A. K., and S. A. Semiletkin (1992), Morphology and evolution of fold and rupture structures in the Talas Alatau, Northern Tien Shan, Geotectonics, 25, 59.

Kiselev, V. V. (1999), The uranium and lead zircon geochronology of igneous rocks in the Northern Tien Shan, in The Problems of Geology and Geography in Kyrgystan, edited by A. B. Bakirov, and A. N. Dikikh (in Russian), p. 21, Ilim, Bishkek.

Kiselev, V. I. (2001), The analogs of the Sinian rock complex in the Middle and Northern Tien Shan, Geol. Geofiz. (in Russian), 42, 1453.

Kiselev, V., F. Apayarov, V. Komartsev, E. Tsyganok, and E. Lukashova (1993), The isotopic age of zircons from the Tien Shan crystalline rocks, in The Early Precambrian Rocks of the Central Asia Fold Belt, edited by I. K. Kozakov (in Russian), p. 99, Nauka, St. Petersburg.

Klishevich, V. L., and S. A. Semiletkin (1995), The Lower Paleozoic terrigenous carbonate rocks in the western part of the Northern and Middle Tien Shan, Bulletin of the Moscow Society of Naturalists, Ser. Geol. (in Russian), 70(2), 59.

Komarevtsev, V. T., V. V. Kiselev, A. V. Mikolaichuk, and E. V. Hristov (1987), Radiogenic dating of South Tien Shan ophiolites, Izv. Acad. Sci. Kirghiz SSR, Ser. Fiz. and Math. (in Russian), 3, 48.

Kurenkov, S. A., A. N. Didenko, and V. A. Simonov (2002), Paleospreading Geodynamics (in Russian), 294 pp., Geos, Moscow.

Liu, X., D. Fu, J. Yao, X. Ding, Y. Wang, S. Wu, Y. Yan, S. N. Graham, E. Chang, and E. Sobel (1997), The Sedimentary-Tectonic Evolution of the Tarim Plate and Its Surrounding Area (in Chinese, 212-257 pp. in English), 257 pp., Xinjang Sci. Techn. Publishing House, Urumqi.

Lomize, M. G., L. I. Demina, and A. A. Zarshchikov (1997), The Kyrgyz-Terskey Paleooceanic Basin, Tien Shan, Geotectonics, 31, 445 .

Maksumova, R. A. (1999), A new type of the Lower Paleozoic rock sequence in the North Tien Shan area, in Problems of geology and geography in Kyrghystan, edited by A. B. Bakirov and A. N. Dikich (in Russian), p. 92, Ilim, Bishkek.

Maksumova, R. A., A. V. Jenchuraeva, and A. V. Berezansky (2001), The major tectonic units and evolution of the Tien Shan orogen, in Paleozoic Geodynamics and Gold Deposits in the Kyrgyz Tien Shan, edited by R. Seltman, and R. Jenchuraeva, IGCP Project 373, IAGOD Guidebook ser., vol. 9, no. 18, p. 17, FAO, London-Bishkek.

Mambetov, A. M., and L. N. Repina (1979), The Lower Cambrian rocks of the Talas Plateau and their correlation with the rock sequences of the Malyi Karatau Ridge and of the Siberian Platform, in The Biostratigraphy and Paleontology of the Siberian Lower Cambrian Rocks, edited by I. T. Zhuravlev and M. P. Meshkov (in Russian), p. 98, Nauka, Novosibirsk.

Mazarovich, O. A., I. S. Barskov, V. I. Borisenok, M. Lomize, R. N. Sobolev, and R. I. Filatova (1995), The North Xinjiang rocks in the system of the Central Asian Paleozoides, The general characteristics and stratigraphic problems, Bulletin of the Moscow Society of Naturalists, Ser. Geology (in Russian), $70(6), 3$.

Melnichuk, V. G. (1987), The main tectonic units of the Garm Massif, Herald of Moscow University (in Russian), Ser. 4(4), 57. 
Melnichuk, V. G. (1989), The tectonic breaking of the Garm Massif (South Tien Shan) and the history of its formation, Bulletin of the Moscow Society of Naturalists, Ser. Geology, $64(2), 34$.

Mikolaichuk, A. V. (1998), The Riphean-Lower Paleozoic rocks of the Issyk Kul massif, Izv. Kyrgyz Acad. Sci. (in Russian), 2-3, 50 .

Mikolaichuk, A. V., S. A. Kurenkov, K. E. Degtyarev, and V. I. Rubtsov (1997), Northern Tien Shan: Main Stages of the geodynamic evolution in the Precambrian-Early Paleozoic, Geotectonics, 31, 445.

Mitrofanov, F. P., (Ed.) (1982), The Precambrian of Middle Asia (in Russian), 264 pp., Nauka, Leningrad.

Mossakovsky, A. A., T. N. Kheraskova, S. V. Ruzhentsev, and S. G. Samygin (1994), Central Asian Fold Belt: Geodynamic evolution and formation history, Geotectonics, 27, 445.

Osmonbetov, K. O., V. I. Knauf, and V. G. Korolev, (Eds.), (1982), The Stratified and Intrusive Rocks of Kirghizia (in Russian), vol. 1 and vol. 2, 357, 245 pp., Ilim, Frunze.

Repina, L. N. (1985a), The paleobiogeography of Early Cambrian seas based on trilobites, in The Paleozoic Biostratigraphy and Biogeography in Siberia, edited by A. V. Kanygin and I. P. Meshkova (in Russian), p. 5, Institute of Geology and Geophysics, Russian Academy, Novosibirsk.

Repina, L. N. (1985b), The Early Cambrian seas of the world and their paleobiogeographic subdivisions based on trilobites, in The Environment and Life in the Geological Past, edited by O. A. Betekhtina and I. T. Zhuravleva (in Russian), p. 5, Nauka, Novosibirsk.

Sakiev, K. S. (1991), The Petrology of the Ophiolitic Rocks in the Kara-Archa Zone of the Northern Tian Shan (in Russian), 184 pp., Ilim, Bishkek.

Sengör, A. M. C., and B. A. Natalin (1996), Paleotectonics of Asia: fragments of synthesis, in The tectonic evolution of Asia, edited by An Yin, M. Harrison, p. 486, University, Cambridge.
Sengör, A. M. C., $\quad$ B. A. Natalin, and V. S. Burtman (1993), Evolution of the Altaid tectonic collage and Palaeozoic crustal grows in Eurasia, Nature, 364(6435), 299.

Travin, A. V., V. A. Simonov, S. A. Kurenkov, Yu. V. Tikunov, D. S. Yudin, and A. V. Mikolaichuk (2002), The first data for the absolute age of the North Tien Shan ophiolites, in The Geology, Geochemistry, and Geophysics at the Boundary between the $X X$ and $X X I$ centuries, vol. 1, edited by M. A. Semikhatov, and S. A. Kurenkov (in Russian), p. 105, Svyaz, Moscow.

Yu, B., H. Dong, J. Chen, X. Li, and C. Lin (2005), Characteristic rare earth and rare element patterns in bedded cherts from the bottom of the Lower Cambrian in the North Tarin Basin of North China and their genetic significance, Acta Geologica Sinica, 79, 215.

Wang, B., Z. Lang, X. Li, X. Qu, T. Li, C. Huang, and X. Cui (1994), Comprehensive Survey of the Geological Sections in the West Tianshan of Xinjiang (in Chinese, except for the last 5 pages which are in English), 200 pp., China, Urumqi.

Zamaletdinov, T. C., and K. O. Osmonbetov (1988), A geodynamic model for the Phanerozoic evolution of the Earth crust in Kirghizia, Soviet Geology J. (in Russian), 1, 66.

Zhao, X., R. S. Coe, R. M. Smith, H. Wu, S. A. Gilder, and H. Pfoutz (1997), New Cambrian and Ordovician paleomagnetic poles from Tarim and their paleogeographic implications, Fall Meeting Abstracts, p. F175, AGU, San Francisco.

Zonenshain, L. P., M. I. Kuzmin, and L. M. Natapov (1990) Geology of the USSR: A plate tectonic synthesis, $A G U$ Geodynamic Series, 21, 250.

V. S. Burtman, Geological Institute of the Russian Academy, 7 Pyzhevskii Lane, Moscow, 119017 Russia (e-mail: burtman@burtman.msk.ru; burtman@ginras.ru) 